\title{
3D kinematics of a thick salt layer during gravity-driven deformation
}

Chris Kirkham ${ }^{1 *}$ Joe Cartwright ${ }^{1}$, Claudia Bertoni ${ }^{1}$, Karyna Rodriguez ${ }^{2}$ and Neil $\operatorname{Hodgson}^{2}$

${ }^{1}$ Department of Earth Sciences, University of Oxford, South Parks Road, Oxford, OX1 $3 \mathrm{AN}, \mathrm{UK}$

${ }^{2}$ Spectrum Geo Ltd. Dukes Court, Duke Street, Woking, Surrey, GU21 5BH, UK

\section{*Corresponding author}

\section{Abstract}

We present the results of an interpretation of 2D and 3D seismic from offshore Lebanon in which we identify a suite of 5 linearly distributed trails of fluid escape pipes with pockmarks at their upper terminus. These features transect the thick Messinian evaporites and root within prominent NE-SW oriented pre-salt folds. The pipe trails are oriented orthogonal to the strike of the pre-salt folds, with a synchronous initial expulsion episode in each trail dated at $1.7 \mathrm{Ma}( \pm 0.3 \mathrm{Ma})$, approximately coeval with the onset of salt-detached growth faulting along the basin margin. Each expulsion episode has been systematically offset to the NW away from the pre-salt fold by the flow of the salt, resulting in deformation of the fluid escape pipes in the salt. The orientation of the pipe trails thus provides a direct kinematic indicator for the flow direction of the salt layer during early stages of gravity-driven deformation of the salt and overburden, concomitant with basin margin uplift and tilting. The unidirectional NW oriented flow is recorded over a region of some $50 \mathrm{~km}$ width within the 
translational domain of the salt tectonic deformation. Synchronicity in the onset of fluid expulsion from overpressured reservoirs within the pre-salt succession evidenced by these pipe trails and growth fault development at the basin margins implies that the pipe trails record the kinematics of the deforming salt layer throughout its post-Messinian phase of deformation. The deformed pipe trails demonstrate a Couette flow regime for the salt layer and document subtle changes in cumulative strain and velocity (2-4 $\mathrm{mm} / \mathrm{yr} ; \pm 0.3 \mathrm{~mm} / \mathrm{yr}$ ) over distances of a few $\mathrm{km}$. It is proposed that this novel method of using fluid flow features as natural markers for the kinematics of deforming salt layers could be utilized in other parts of Eastern Mediterranean, as well as other salt basins on Earth.

Keywords: Salt tectonics, 3D salt kinematics, Focused fluid flow, Fluid escape pipes, Pockmarks, Messinian Salinity Crisis, Eastern Mediterranean, Continental margins

\section{Introduction}

Reconstructing the kinematics of thick, autochthonous salt layers and relating them to the boundary conditions driving deformation is a major goal of salt tectonics (Kehle, 1988, Rowan et al., 2004, Brun and Fort, 2011, Quirk et al., 2012, Peel, 2014). Thick salt layers are widely developed in the geological record, and their gravity-driven deformation in particular has had a major controlling influence on the structure and stratigraphy of many passive continental margin, rift and foreland basins, from the Proterozoic to the Recent (Jackson and Hudec, 2017).

The flow within salt layers is governed by several factors, gravity forces, resistive forces and rheology (Jackson and Hudec, 2017). To date, our understanding of the flow 
regime of salt layers deforming under gravity derives almost entirely from numerical and analogue modelling (Davison et al., 1996, Albertz and Ings, 2012), using rheologies and flow laws obtained from the laboratory (Urai and Spiers, 2007, Urai et al., 2008). Different types of flow regime are predicted depending on these boundary conditions, and can be dominantly Poiseuille, Couette, or Squeeze flow, or various combinations of these three end members (Jackson and Hudec, 2017). Gravity gliding is typically linked to flow in a Couette regime, whereas gravity spreading usually involves a significant component of Poiseuille flow (Gemmer et al., 2004, Albertz and Ings, 2012). Drainage of salt due to basin tilting has recently been suggested to be an important feature of early stage deformation of salt basins (Quirk et al., 2012), with flow dominated by Couette regime distally, and by Poiseuille proximally.

Most studies of salt flow rate in a geological context have focused on 2D numerical modelling of diapirs or salt extrusions (Talbot, 1998, Mukherjee et al., 2010), with only a few three-dimensional numerical modelling studies of diapirs (Kaus and Podladchikov, 2001, Ismail-Zadeh et al., 2004). Direct, in situ measurements of flow velocity have thus far been almost entirely made using surface measurements, and only then on extrusive salt glaciers and salt diapirs rather than autochthonous salt layers (Talbot, 1998, Weinberger et al., 2006; see tables in pages 48-50 in Jackson and Hudec, 2017). Hence the large suite of numerical models is largely uncalibrated for regional scale flow behaviour of the salt layers.

Recently, Cartwright et al. (2018) outlined a new approach to calibrating the internal kinematics of salt layers, using deformed fluid escape pipes and their associated seafloor pockmarks as strain markers. Cartwright et al. (2018) observed a diachronous trail of pockmarks offshore Lebanon, using 3D seismic data, and related the pockmarks to deformed fluid escape pipes emanating from the crest of a major anticlinal structure 
at the base of the salt layer. The pockmark trail was dated to a period spanning the last 1.7 $\mathrm{Ma}( \pm 0.3 \mathrm{Ma})$, which allowed the average velocity of the top salt surface to be calculated (Cartwright et al., 2018). The deformed pipe geometry could be interpreted from the $3 \mathrm{D}$ seismic and this provided the key constraint that the flow regime was almost pure Couette, with the overburden fully coupled to the top salt and the pre-salt coupled to the base salt with no detachment (Cartwright et al., 2018). From these observations, (Cartwright et al., 2018) calculated shear strain rate and the dynamic viscosity. However, these observations only constrained the kinematics in a single location, and thus gave only a first order, two-dimensional constraint on the kinematics of a small region of a much larger salt layer. The main aim of this paper is to demonstrate the potential for application of this approach to constrain flow kinematics of the salt layer in three dimensions. The ability to constrain the flow regime on a basin scale would be a major contribution in the larger task of unravelling the drivers and responses involved in gravity-driven salt tectonics.

Here we extend the novel approach developed by Cartwright et al. (2018) by using an areally distributed set of strain markers for deformation through the salt to constrain salt flow in three dimensions. We identify 5 separate pockmark trails developed above two widely separated $(46 \mathrm{~km})$ pre-salt anticlines, that represent strain markers for flow of the salt over an area of $100 \mathrm{~s}$ of $\mathrm{km}^{2}$. Geometrical interpretation and reconstruction of the deformed fluid escape pipes allows quantification of the large shear strains developed during early-stage salt tectonics, and demonstrates a Couette flow profile of the salt layer in the translational domain of the gravity-driven tectonic system.

We date the onset of the pipe/pockmark trails, showing that this is synchronous for all 5 trails at c. $1.7 \mathrm{Ma}( \pm 0.3 \mathrm{Ma})$, and link their expulsion with the onset of salt flow at the margins through interpretation of growth faults in the extensional domain. Finally, 
we relate the three-dimensional flow kinematics of the salt layer to the boundary conditions driving the deformation of the salt layer, and discuss the wider implications for early-stage salt tectonics in general.

\section{Geological Setting}

The study area is located in the North Levant Basin, offshore Lebanon (Fig. 1). The main marker horizons, stratigraphic units and description of their seismic facies is summarised in Figure 2. The stratigraphy within the deep water North Levant Basin has not yet been drilled and is poorly constrained, with the main stratigraphic framework being derived and extrapolated from the South Levant Basin (Druckman et al., 1995, Gardosh and Druckman, 2006, Gvirtzman et al., 2017).

The Mesozoic units underlying the Senonian Unconformity (Figs. 1C \& 2) are characterised by deepwater carbonates and clastics (Ghalayini et al., 2018). A predominately clastic, $>8 \mathrm{~km}$ thick Cenozoic sedimentary sequence overlies the Mesozoic succession (Figs. 1C \& 2). The siliciclastic deposits of the Oligo-Miocene (Figs. 1C \& 2) were sourced predominantly from the proto-Nile Delta, with other currently unproven but postulated sediment sources from Syria and Lebanon proposed to have also contributed (Hawie et al., 2013, Ghalayini et al., 2018). The Oligo-Miocene is primarily characterised by parallelism of the stratal reflections (Fig. 2) over large distances, reflecting the deepwater setting of the clastic depositional system (Gardosh and Druckman, 2006). These deepwater clastic sediments are transected by normal faults oriented NW-SE that detach within the deeper Cenozoic (Fig. 3) (Kosi et al., 2012, Reiche et al., 2014, Ghalayini et al., 2017). 
A c. $1.5 \mathrm{~km}$ thick (Bertoni et al., 2017), dominantly halite succession was deposited during the Messinian Salinity Crisis (MSC) over much of the basin. This is succeeded by the Plio-Pleistocene prograding wedge of mainly fine-grained siliciclastics (Figs. 1C \& 2) (Lofi, 2018).

The North Levant Basin is located in a tectonically active region with subduction of the African plate beneath the Eurasian plate since the late Cretaceous and formation of the Cyprus Arc System, including the Latakia Ridge (Fig. 1A \& B) (Robertson et al., 1996, Ghalayini et al., 2018). Regional compression during convergence and suturing of Arabia with Eurasia in the Oligo-Miocene led to the formation of a set of NE-SW trending anticlines (Gardosh and Druckman, 2006, Ghalayini et al., 2018). Activity of the sinistral Levant Fracture System, extending from Israel through to Syria (Fig. 1B), led to increased marginal uplift from the Mid Miocene (Hawie et al., 2013, Ghalayini et al., 2018). Regional uplift of the hinterland immediately updip of the basin margin in the Levant Basin was concurrent with the development of major structures including Mount Lebanon and the Judean Mountains (Fig. 1A) (Nader, 2011, Bar et al., 2016, Ghalayini et al., 2018). The rate of uplift of Mount Lebanon increased in the Late Miocene to Pliocene (Walley, 1998, Ghalayini et al., 2018). The Judean Mountains were uplifted $\sim 350$ m during the most recent Late Pliocene to Recent phase (Bar et al., 2016). The most recent phase of uplift was recorded by a change in drainage direction in northern Israel staring at 1.8 Ma (Matmon et al., 1999).

Salt-detached gravity-driven tectonics commenced in the Levant Basin during the latest Messinian driven by marginal uplift and basin tilting, followed by a second phase of deformation in the Late Pliocene to Recent (Netzeband et al., 2006, Bertoni and Cartwright, 2007, Gvirtzman et al., 2013, Feng et al., 2017). The widespread salt flow during this most recent phase of deformation has led to the development of an 
extensional domain around the basin margins that transitions basinward into a translational domain and contractional salt tectonics in the basin centre (Fig. 1B) (Gradmann et al., 2005, Cartwright and Jackson, 2008). A belt of growth faults extends over the $\sim 400 \mathrm{~km}$ long extensional domain, in a configuration parallel with the continent along the eastern margin of the Levant Basin (Fig, 1B \& 1C). Folding of the Plio-Pleistocene Unit extends over an area of $31000 \mathrm{~km}^{2}$ in the deeper basin contractional domain, with a dominant NE-SW orientation parallel with the basin margin in the North Levant Basin (Fig. 1B \& 1C) (Cartwright et al., 2018). The PlioPleistocene overburden in the translational domain is only weakly deformed and is distributed in a configuration grossly parallel to the basin margin and the extensional domain (Fig. 1B \& 1C).

The gross kinematics of salt flow in the translational domain of the North Levant Basin is directed basinward orthogonal to the strike of the extensional faults and the PlioPleistocene folds. The regional flow regime for the eastern margin of the Levant Basin is therefore consistent with gravity tectonics driven by basinward tilting of the margin combined with an element of differential loading between the slope and basin floor (Gradmann et al., 2005, Loncke et al., 2006, Cartwright and Jackson, 2008, Gvirtzman et al., 2013, Allen et al., 2016).

\section{Data Methods}

\subsection{Seismic data and well calibration}

Two regional 2D seismic surveys were used in this study, EMED-00 Broadband Repro 2016-17 in both time and depth migration and Leb02 Repro 2012 (Fig. 1A). The EMED-00 2D seismic survey has a total line length of $12000 \mathrm{~km}$ and a 10-30 km line 
spacing. It was acquired in 2000 with a streamer length of $7200 \mathrm{~m}$ and record length of 12 s. The data was reprocessed using a broadband methodology in 2017 and depth migrated in 2019 by Spectrum. The Leb02 2D seismic survey has a line length of 2006 $\mathrm{km}$ with a line spacing of $5-10 \mathrm{~km}$. The $2 \mathrm{D}$ survey was acquired in 2002 with a streamer length of $6000 \mathrm{~m}$ and record length of $9 \mathrm{~s}$ and reprocessed in 2012. A post-stack time migrated 3D reflection seismic survey covering $5350 \mathrm{~km}^{2}$ of the deep water region of Lebanon (LEB3D-12) was also interpreted for this study (Fig. 1A). It was acquired by Spectrum in 2012, processed to zero phase and displayed with SEG normal polarity such that acoustically 'hard' reflections are displayed as positive amplitudes. A bin spacing of $12.5 \mathrm{~m}$ yields a lateral resolution of $25 \mathrm{~m}$. Vertical resolutions vary with depth, from c. $10 \mathrm{~m}$ within the post-salt overburden to c. $40 \mathrm{~m}$ within the salt. Interval velocities for the key stratigraphic units are extrapolated from exploration wells further to the south in the Levant Basin (Gardosh and Druckman, 2006, Feng et al., 2016). Pwave velocities of $2,000 \mathrm{~m} / \mathrm{s}, 4,200 \mathrm{~m} / \mathrm{s}$ and $3000 \mathrm{~m} / \mathrm{s}$ were assumed for the post-salt overburden, the Messinian Evaporite Unit, and the pre-salt Miocene clastics, respectively (Figs. 1C \& 2).

Exploration wells (Or-South-1, Nir-1 and Gaza-Marine-1) in the South Levant Basin have been used for long range calibration (c. $195 \mathrm{~km}$ ) to the North Levant Basin of the Gelasian-Calabrian boundary (after Cartwright et al. (2018), dated at $1.806 \mathrm{My}$. The top of Zone NN18 (1.95 Ma) is demarcated by the highest and last occurrence of $D$. brouweri (Catalano et al., 1998). A downhole decrease in the recovery of Gephyrocapsa spp. (Rio et al., 1997) and the first occurrence of G.tenellus, B. etnea and H. baltica (Barbieri et al., 1998) define the lowermost section of the Calabrian.

Seismic interpretation was undertaken using Schlumberger's Petrel 3D seismic software platform. Key marker horizons including the seafloor, Gelasian/Calabrian 
boundary, top-salt, base-salt or bottom erosional surface (BES), Base Miocene, Upper Oligocene and Senonian Unconformity (Fig. 2) have been mapped throughout the regional 2D data and 3D seismic surveys. A root mean square (RMS) amplitude seismic volume (Brown, 2011) was interpreted to identify localised high amplitudes attributed to fluid escape pipes in the Messinian Evaporite Unit. Coherency attribute volumes (Brown, 2011) were used to support interpretation of the discontinuities associated with fluid escape pipes in the Plio-Pleistocene. A comprehensive structural interpretation of the overburden was undertaken throughout the study area to provide additional context to the main focus of interpreting fluid escape features (see next section). Fault measurements including fault height, throw, heave at the top salt and spacing were recorded from growth faults in the extensional domain in the North Levant Basin, using a similar methodology to that presented in Cartwright and Jackson (2008) for their study of the South Levant Basin. Fold axis orientations and positions were recorded for the overburden within the translational and contractional domains of the study area.

\subsection{Interpreting focused fluid flow features}

Fluid escape pipes and pockmarks were identified in this study based on previously established diagnostic characteristics from fluid escape structures identified in other basins (Moss and Cartwright, 2010, Cartwright and Santamarina, 2015, Cartwright et al., 2018, Kirkham et al., 2018b). Fluid escape pipes typically root to structures that present natural leak-off points for overpressured fluid such as the crest of anticlines, footwall crests, the up-dip pinch-out of a reservoir and structural weaknesses created by fault planes (Judd and Hovland, 2009, Løseth et al., 2009, Cartwright and Santamarina, 2015, Cartwright et al., 2018). Pockmarks are commonly found at the upper terminus of fluid escape pipes in situations where fluids have been expelled at a 
present day or a palaeo-seafloor (Løseth et al., 2009, Moss and Cartwright, 2010). Their interpretation was critical in this study for constraining the timing of fluid expulsion via the fluid escape pipes.

\section{Results}

The study area encompasses the updip extensional domain along with portions of the translational-contractional domain of the North Levant Basin (Fig. 1B). Regional mapping of the Base Mid Miocene offshore Lebanon reveals several pre-salt folds oriented NNE-SSW/NE-SW (Fig. 3A). The description below concentrates primarily on two of these folds, with a focus on their structural interpretation and evidence of focused fluid flow from their crestal regions. The first of these structures and the focused fluid flow above it was first documented by Cartwright et al. (2018) and is described in greater detail here. The final section focuses on a more detailed description of the growth faults in the extensional domain.

\subsection{Structural interpretation of the Oceanus Structure}

One of the most prominent of the pre-salt folds is located within the central region of the LEB3D-12 seismic survey and is known as the Oceanus Structure (Cartwright et al., 2018). The fold is oriented NE-SW, is c. $10 \mathrm{~km}$ long, has a width of c. $3 \mathrm{~km}$ and a maximum amplitude of c. $>600 \mathrm{~m}$ recorded at the Top Oligocene marker (Figs 3B \& C). It is bounded by outward facing reverse faults that define the lateral margins of the fold (Fig. 3C). Reflection-bound packages between the horizons of the Base Mid Miocene and the BES systematically thin toward the fold (Fig. 3C). Reflections within the thinning packages just beneath the BES onlap the fold and have been tilted upward 
toward the fold's crest (Fig. 3C). Neither the fold nor outward facing reverse faults are evident on the underlying Senonian Unconformity (Fig. 3C).

At the BES, the fold has a structural relief of c. $300 \mathrm{~m}$ and is asymmetric, with angles of $9^{\circ}$ and $6^{\circ}$ for the NW and SE fold limbs respectively (Fig. 3C). The gross slope angle of the BES in this central part of the basin is c. $2^{\circ}$ to the NW. The thickness of the Messinian Evaporite Unit is uniformly $\sim 1500 \mathrm{~m}$ on both the NW and SE side of the fold, thinning to $\sim 1200 \mathrm{~m}$ above the crest of the fold (Fig. 3C). There is considerably greater localised deformation within the Messinian Evaporite Unit in the immediate environs of the fold than in areas outwith the margins of the fold, and the lower reflective layers in the Messinian Evaporite Unit exhibit some concordance with the BES and breaks in their continuity (Fig. 3C). There is no evidence in the PlioPleistocene of depositional packages thinning onto any folding concordant with the underlying pre-salt fold (Fig. 3C). However, the Plio-Pleistocene displays a $40 \mathrm{~m}$ increase in thickness forming an asymmetric minibasin above the NW flank of the presalt fold (Fig. 3C \& 4A). The reflections within this minibasin exhibit a sigmoidal geometry, dipping landward with onlap onto a basal surface (Fig. 3C \& 4A).

\subsection{Oceanus pipe trail}

Recently Cartwright et al. (2018) demonstrated that the Oceanus Structure is a locus for episodic focused fluid escape through the Messinian Evaporite Unit in the North Levant Basin (Fig. 4). This fluid escape is expressed at the present day seafloor as a c. $500 \mathrm{~m}$ wide pockmark that is located directly above the crest of the Oceanus Structure (Figs. 4A \& B). The Oceanus Structure and the pockmark are connected by a c. $150 \mathrm{~m}$ wide and $>1800 \mathrm{~m}$ tall fluid escape pipe that transects the entire Messinian Evaporite and Plio-Pleistocene units (Figs. 4B \& C). The fluid escape pipe is interpreted as a circular 
to elliptical area of discontinuity in planform when using the coherency attribute, which also highlights a further 20 pipes distributed linearly toward the NW (Fig. 4D; Table 1). Their distribution is perpendicular to the extensional domain and parallel to the salt flow direction (Fig. 1B).

Each pipe in the linear trail has a pockmark at its upper terminus and each of these pockmarks is positioned at a different stratigraphic depth in the Plio-Pleistocene (Figs. 4A-C). The pockmarks exhibit diameters ranging from $58-254 \mathrm{~m}$ and are spaced at distances ranging from $93-419 \mathrm{~m}(+/-10 \%)$ with an average and median of $184 \mathrm{~m}$ and $149 \mathrm{~m}$, respectively (Table 1). The oldest pockmark to have formed (Fig. 4C) is located at the distal limit of the NW oriented linear trail, with the age of the pockmarks progressively younging to the SE (Figs. 4A), toward the pockmark at the present day seafloor (Fig. 4B). The oldest pockmark is dated as c. $1.7 \mathrm{Ma}$ (+/- $0.3 \mathrm{Ma}$ ) (Fig. 4C) based on regional mapping and calibration of the Gelasian-Calabrian boundary.

The pipe and pockmark trail extends over a distance of $3.4 \mathrm{~km}$ (Table 1) from the crestal position of the Oceanus Structure (Fig. 3B). The linear trail of pockmarks is underlain by a NW-SE oriented linear trail of disrupted seismic reflectors and amplitude anomalies within the Messinian Evaporite Unit (Fig. 4A). This acoustically turbulent area is bound at its base by a continuous, curved, high amplitude reflection (referred to by Cartwright et al. (2018) as Reflection X), that is c. $150 \mathrm{~m}$ wide and extends from beneath the oldest pockmark in the trail to the crest of the Oceanus Structure at the BES (Fig. 4A). The geometry of this anomalous reflection is divergent to the laterally continuous intra-salt reflections (Fig. 4A).

\subsection{Structural interpretation of the Saida-Tyr Structure}


The western margin of the Saida-Tyr Plateau (Fig. 1A) (Ghalayini et al., 2018, Nader et al., 2018) is host to a pair of prominent pre-salt folds (Fold A and Fold B; Fig. 5A), recently interpreted by Ghalayini et al. (2018) as transpressive anticlines consisting of pre-existing structures that were reactivated in the Late Miocene. The most outboard of these folds (Fold B; Fig. 5A) is located $2 \mathrm{~km}$ east of the LEB3D-12 survey (Figs. 5A \& B), approximately $45 \mathrm{~km}$ SE of the Oceanus Structure. These two folds can be interpreted on two of the EMED-00 2D seismic lines that are oriented NW-SE and are spaced c. $13.5 \mathrm{~km}$ apart (2D lines 1 and 2D line 2; Fig. 5B). The most inboard of the two folds named here Fold A (Fig. 5A) is interpretable on the most northern of the two 2D lines (labelled 2D line 1 on Fig. 5B). Fold A is c. $3.4 \mathrm{~km}$ wide, symmetric, has a maximum amplitude of $>640 \mathrm{~m}$ (at the Base Mid Miocene) and is located $5 \mathrm{~km}$ to the west of the more prominent Fold B (Fig. 5A).

Fold B can be interpreted on 2D line 1 (Fig. 5A) as well as the next 2D line to the south 2D lines 2 (Figs. 5B \& C). Fold B exhibits contrasts in geometry between 2D line 1 and 2D line 2. On 2D line 2, Fold B is $4.5 \mathrm{~km}$ wide, has a maximum fold amplitude at the Base Mid Miocene of c. 850 m, and structural relief at the BES of c. 300 m (Fig. 5C). The Messinian Evaporite Unit above Fold B in 2D line 2 exhibits modest variability in thickness over the fold from $\sim 1375 \mathrm{~m}$ on its NW side, reducing to $\sim 1160 \mathrm{~m}$ on the SE side and decreasing to $\sim 875 \mathrm{~m}$ above the crest of the structure (Fig. $5 \mathrm{C}$ ). Fold $\mathrm{B}$ is bounded on its NW and SE side by inward dipping reverse faults, similar to the Oceanus Structure.

In contrast, Fold B exhibits greater intensity of deformation in 2D line 1, with a width of c. $7.8 \mathrm{~km}$ and its amplitude reaches c. > $1050 \mathrm{~m}$ (Fig. 5A). Imaging within the fold in $2 \mathrm{D}$ line 1 is poor and made more challenging without 3D seismic coverage. However, reverse throws of $>200 \mathrm{~m}$ across the steep faults bounding the anticline at the level of 
the BES can be clearly observed (Fig. 5A). Reflection bound packages within the upper Miocene section, particularly between the Top Mid Miocene and the BES horizons, display thinning onto the structure (Fig. 5A \& 5C). The average slope angle at the BES is c. $2.5^{\circ}$ and the fold amplitude at the BES is $>560 \mathrm{~m}$ (Fig. 5A). The thickness of the Messinian Evaporite Unit varies substantially across Fold B in 2D line 1, exhibiting a thickness of $\sim 1670 \mathrm{~m}$ on its NW side, thinning to $\sim 1140 \mathrm{~m}$ on its SE side and decreasing to as little as $\sim 570 \mathrm{~m}$ above the crest of the fold (Fig. 5A). The crest of Fold B can be interpolated between 2D lines $1 \& 2$, defining a NE-SW oriented fold axis (Fig. 5B), i.e. similar in trend to the Oceanus Structure.

As it is located at the margin of the basin dipping ramp of the Saida-Tyr Plateau, from this point onward the prominent structure of Fold B will be referred to as the Sadia-Tyr Structure. Similar to the Oceanus Structure, the fold of the Saida-Tyr Structure is asymmetric with a comparable SE fold limb angle at the BES of $5^{\circ}$, but a significantly steeper and concave curving NW fold limb with an angle of up to $19^{\circ}$ (Fig. 5A). The Messinian Evaporite and Plio-Pleistocene units above the Saida-Tyr Structure do not show any evidence of syn-kinematic thinning onto the fold crest. However there is an obvious thinning of the salt over the fold relative to the background basinal thickness similar to that seen above the Oceanus Structure (Fig. 5A). Also comparable to Oceanus Structure is the presence of an asymmetric minibasin in the Plio-Pleistocene Unit above the NW flank of the pre-salt Saida-Tyr Structure, which contains reflections with a sigmoidal and landward dipping geometry (Fig. 5A \& 6A).

\subsection{Saida-Tyr pipe trail}

A cluster of 84 fluid escape pipes and pockmarks are observed within the most southeasterly portion of the 3D seismic survey. Four NW-SE oriented linear trails of fluid 
escape pipes and pockmarks, named STP1- STP4 (STP = Saida-Tyr pockmark trail) have been interpreted within this cluster (Fig. 6). These four trails are almost parallel to one another (Fig. 6D) with only a $4^{\circ}$ range in measured strike values between all four trails, but with a $\sim 20^{\circ}$ contrast in orientation compared to the pipe trail above the Oceanus Structure (Fig. 3B; Table 1). The spacing between adjacent trails varies, STP1STP2 are the closest (300 m), and STP3 and STP4 are the most widely separated (2250 m). The oldest pockmark in each linear distribution is the most distal (Fig. 6A \& 6B). The age of the pockmarks therefore progressively youngs toward the SE (Fig. 6A \& 6C), similar to the trail linked to the Oceanus Structure, but in contrast, the age of the most recent expulsion episode is unknown for STP1-STP4. Seismic correlation does allow us to constrain the age of the initial pockmark in each trail, and within seismic resolution limits these all formed at the same horizon $(1.7 \mathrm{Ma}+/-0.3 \mathrm{Ma})$.

The diameter of the pockmarks in the four trails ranges from $50 \mathrm{~m}$ to $212 \mathrm{~m}$ and their spacing sequentially is irregular with distances ranging from $30 \mathrm{~m}$ to $654 \mathrm{~m}$ and an average spacing in each trail ranging from $159 \mathrm{~m}$ to $288 \mathrm{~m}$ (Table 1). By analogy with the Oceanus Structure, the crest of the Saida-Tyr Structure is the most likely natural leak-off point and root zone for these fluid escape pipes. The distance between the first pockmark in STP1-STP4 and the crest of the Saida-Tyr Structure ranges from c. $6.6-$ $8 \mathrm{~km}(+/-10 \%$ due to uncertainty in the exact position of the crest of the fold; Table 1). The Messinian Evaporite Unit underlying STP1-STP4 is characterised internally by several regionally extensive, highly deformed intra-salt reflections (commonly referred to as ME20-ME60; see Bertoni and Cartwright (2006) and Lofi et al. (2011)). In addition to this 'background' complexly deformed internal reflectivity, we interpreted a number of anomalous acoustically 'soft' high amplitude reflections that are localised, linear and are only observed directly underlying the pockmark trails (Fig. 7). The cross- 
section in Fig. 7A is along strike of STP3 and displays one of these anomalous reflections in the Messinian Evaporite Unit that directly underlies the pipe trail in the Plio-Pleistocene Unit. The anomalous reflection extends from top salt beneath the most distal NW pockmark in STP3, through the Messinian Evaporite Unit at an angle of c. $5^{\circ}$ (a corrected angle of $15^{\circ}$ subtended with respect to a flattened top salt, toward the Saida-Tyr Structure to the SE (Fig. 7A).

It is more challenging to interpret in the Messinian Evaporite Unit directly beneath the linear trail of pipes where there is significant acoustic turbidity and imaging artefacts shroud the anomalous reflection (Fig. 7A). RMS amplitude slices (Fig. 7B) are effective in imaging this anomalous reflection in planform as a linear trail of amplification within the Messinian Evaporite Unit, orientated NW-SE similar to the distribution of pockmarks in the Plio-Pleistocene overburden. Seismic cross-sections perpendicular to the strike of the anomalous reflection and STP3 (Fig. 7C-7E) demonstrate that the anomalous reflection is a localised linear feature. Its position in the salt progressively deepens (Fig. 7C-7E) toward the SE and is geometrically divergent to and distinguishable from the regional intra-salt reflections (Fig. 7A). The anomalous reflection is analogous to the high amplitude reflection (Reflection $\mathrm{X}$ ) described beneath the Oceanus pockmark trail (Fig. 4A). However, due to the limits of the 3D seismic survey boundary it is not possible to observe the most south-easterly section of the anomalous reflection to see if it extends to the very crest of the Saida-Tyr Structure at the BES, similar to the relationship between Reflection X and the crest of the Oceanus Structure.

\subsection{The extensional domain}


The extensional domain of the North Levant Basin is poorly described compared to the extensively studied South Levant Basin (Garfunkel, 1984, Gradmann et al., 2005, Cartwright and Jackson, 2008). In the North Levant Basin, the extensional domain comprises a c. $1.5 \mathrm{~km}$ to $30 \mathrm{~km}$ wide array of growth faults (Fig. 8A) that vary in geometry from planar to listric within the Plio-Pleistocene unit and detach within the Messinian Evaporite Unit. These faults strike N-S to NNE-SSW parallel to the basin margin (Fig. 8) and are generally 5-10 km long with a few of the larger faults reaching $>15 \mathrm{~km}$ in length. Fault spacing is variable with distances of few 100s of meters to as great as $13 \mathrm{~km}$ with an average spacing of $1.2 \mathrm{~km}$ and increasing frequency toward the lateral pinch out of the salt (Figs. 8A \& 8B).

The growth faults exhibit a variety of throw values ranging from few $10 \mathrm{~s}$ of meters to $>400 \mathrm{~m}$, while heaves of few 10 s of meters to $>2600 \mathrm{~m}$, with an average of $340 \mathrm{~m}$ are recorded (Fig, 8B \& 8C). Cumulative heave measurements range from c. $\sim 100 \mathrm{~m}$ to $\mathrm{c}$. $>6 \mathrm{~km}$ with a median of $2750 \mathrm{~m}(+\sim 500 \mathrm{~m})$ along the entire margin (Fig. 8B). The thickness of the Plio-Pleistocene overburden at the lateral pinch out of the salt varies from as little as $400 \mathrm{~m}$ toward the north of the study area, to $>1000 \mathrm{~m}$ in the south.

The Gelasian-Calabrian boundary can be further extended from the linear pockmark trails described above, to the extensional domain offshore Lebanon, to assist with dating growth in the extensional faults (Fig. 9). Figure 9 demonstrates only minor growth of few 10s of meters in the hanging wall prior to the Gelasian-Calabrian boundary, with the majority of growth, as much as $300 \mathrm{~m}$, recorded in the last $1.8 \mathrm{Ma}( \pm 0.3 \mathrm{Ma})$.

\subsection{Interpretation of the fluid escape pipes in their structural context}

The 5 linear trails of fluid escape pipes recognised from within the study area emanate from two widely separated NE-SW trending pre-salt folds (Fig. 4 \& Fig. 6). It is 
important to evaluate the growth history of both structures to see if there is any relationship between deformation and fluid escape.

The Oceanus Structure is interpreted to detach at some point within the basal Cenozoic or latest Cretaceous units, based on the lack of any fold relief on the Senonian Unconformity (Fig. 3C), similar to the pre-salt normal faults that detach within the deeper Cenozoic (Kosi et al., 2012, Reiche et al., 2014, Ghalayini et al., 2017). The deeper structural configuration of the Saida-Tyr Structure cannot be interpreted here due to a low signal to noise ratio and scattering within and beneath the fold (Fig. 5). Asymmetric minibasins in the Plio-Pleistocene located just basinward of the Oceanus and Sadia-Tyr Structures (Figs. 3-7) are analogous to Ramp-Syncline Basins (RSBs), described in other salt basins including the Kwanza Basin (Jackson and Hudec, 2005) offshore Morocco (Pichel et al., 2019) and in the Santos Basin (Pichel et al., 2018). By analogy, these may have formed by translation of the salt and its overburden over the structural high at the BES and the landward dip direction of their reflections is the opposite to the salt flow direction (Jackson and Hudec, 2017, Pichel et al., 2018). However, the geometrical interpretation of these RSBs is made more complicated by the action of contour currents, known to be active along this margin at this time (Bertoni, 2006).

The onset of fold growth for both the Oceanus and Saida-Tyr Structures was similar, commencing in the Mid-Late Miocene, based on the evidence of syn-kinematic growth packages (Fig. 3C, 5A \& 5C). Despite relief of several 100s of metres at the BES and thinning of the Messinian Evaporite Unit above these pre-salt folds, there is no growth above the BES associated with further amplification of these folds during the PlioPleistocene (Fig. 3 \& Fig. 5).

There are three possibilities for the growth history of these two important anticlines: 
(1) A single phase of folding within the Mid-Late Miocene, and predating salt deposition; (2) A single phase extending from Mid Miocene through into the period of salt deposition; and (3) Two discrete phases of folding, in the Mid-Late Miocene (represented by the syn-kinematic thickness variations), and a later Pliocene to Recent phase. The first does not explain the significant anticlinal structural relief of $560 \mathrm{~m}$ at the BES. The second is difficult to reconcile with the parallelism of the basal Messinian reflections and concordance with the BES across the fold axis (Figs. 3-5). We suggest that the third possibility is most likely based on the growth history of other nearby prominent structures including the Latakia Ridge and Mount Lebanon. These are known to have undergone a period of growth during the Plio-Quaternary (Hall et al., 2005, Ghalayini et al., 2018). The concordantly folded geometry of the reflective layers in the lower part of the Messinian Evaporite Unit (Figs. 3A \& 4A) argues that salt was deposited and then deformed by later fold amplification. Upwards propagation of the fold structure into the post-salt overburden would have been inhibited by the decoupling behaviour of the thick salt layer (see pages 324-325 in Jackson and Hudec, 2017). This post-Messinian phase of folding is important to recognise, even if not dated precisely, because continued amplification of the folds may have influenced the flow kinematics in the overlying salt unit (see Discussion below).

The interpretation of fluid escape features overlying the Oceanus and Saida-Tyr Structures demonstrate that these prominent pre-salt structures are the loci for the expulsion of overpressured fluids from the pre-salt. The 5 linear distributions of fluid escape pipes with pockmarks at their upper terminus above the Oceanus and Saida-Tyr Structures are all orientated NW-SE (Fig. 4 \& Fig. 6). The age of the pockmarks in all of the linear trails systematically youngs toward the SE in the direction of the fold (Fig. 4C \& Fig. 6B). We interpret that the oldest pockmark in each linear trail was originally 
located above the fold, but via a cyclical process of fluid expulsion contemporaneous with salt flow to the NW (Figs. 1B \& 8A), the pockmark was displaced northwestwards, whilst a new pockmark formed above the fold. The first pockmark in all 5 trails dates the onset of fluid expulsion at $1.7 \mathrm{Ma}( \pm 0.3 \mathrm{Ma})$ (Fig. 4C \& Fig. 6B) and records the flow distance/cumulative strain over that period of time (1.7 Ma $\pm 0.3 \mathrm{Ma}$ ), from above the crest of the pre-salt fold to its present location, from which maximum flow velocities 2-4 $( \pm 0.3) \mathrm{mm} / \mathrm{yr}$ are calculated (Table 1).

The localised linear amplitude anomalies that obliquely transect the salt from beneath the oldest pockmarks towards the fold axis at the BES at the Oceanus and Saida-Tyr Structures (Figs. 4A \& 7) are interpreted as a fluid escape pipes that were originally vertical but have been deformed by the flow of the salt (Cartwright et al., 2018). The crestal position of the present day pipe above the Oceanus Structure (Figs. 4A \& B) is indicative of its likely origin as a response to the bleed-off of extreme overpressures developed within expected Oligo-Miocene reservoirs (Cartwright et al. 2018). The geometry of these deformed pipes is consistent with the deformation of an originally vertical cylindrical structure within a dominantly Couette flow regime.

Coupling of the deformed fluid escape pipe (Reflection X) with the crest of the Oceanus Structure (Fig. 4A) implies that the flow velocity decreases down through the salt reaching zero at its base with no detachment between the base of the salt and the presalt. However as demonstrated in Figure 7, where the deformed pipes above the SaidaTyr Structure intersect the fold at the BES is outside the margins of the 3D seismic survey. The deformed fluid escape pipe above the Saida-Tyr Structure, therefore demonstrates a Couette flow regime in the upper section of the salt, but there is uncertainty in the nature of the flow regime in the lower section of the salt layer due to the absence of 3D seismic coverage. 
The amplitude and geometry along the strike of the fold varies significantly (Figs. 5A \& 5C). The composite seismic cross-section in Figure 6E uses the 3D seismic survey and nearest 2D seismic line that extends to the Saida-Tyr Structure to show the deformed pipe beneath STP3 extending obliquely through the Messinian Evaporite Unit towards the Saida-Tyr Structure. The composite 2D line deviates $30^{\circ}$ off strike of STP3 (Fig, 6E). Based on the trajectory of the deformed pipe through the Messinian Evaporite Unit, unless the amplitude of the fold decreases significantly to the southwest, the pipe should intersect the fold $\sim 2 \mathrm{~km}$ downflank from its crest. The crestal point of the fold represents the natural leak-off position for overpressured fluids, similar to above the Oceanus Structure (Fig. 4), therefore it is unlikely that the deformed fluid escape pipe originally emanated from a position such a long way down the frontal limb.

Two explanations are possible for the geometry shown in Figure 10: (1) the flow regime in the lower salt sequence deviated from that of a simple linear Couette flow regime (Fig. 10) or (2) the base of the deformed pipe was sheared off from the pre-salt at the much steeper north-western flank of the fold (Fig. 10). It is conceivable that the higher salt flow velocity at the Saida-Tyr Structure compared to the Oceanus Structure, combined with the continued amplification of the fold, could have been responsible for this geometry, together with the possibility of salt flux mismatches over the base-salt ramp (Dooley et al., 2018, Pichel et al., 2019). The uncertainty in this interpretation and the range of geometrical possibilities for the lower section of the deformed pipes are schematically demonstrated in Figure 10. Nevertheless, we suggest that the flow regime in this translational-contractional part of the basin to be dominantly Couette Flow, as demonstrated by the deformed pipe above the Oceanus Structure, with only local modifications, exemplified by the Saida-Tyr Structure. 
The distribution and orientation of the extensional domain indicates that the salt flow direction is perpendicular to the basin margin (Figs 1B \& 8A). The initiation of significant growth faulting within the extensional domain is dated as post $\sim 1.8 \mathrm{Ma}( \pm 0.3$ Ma), which constrains the onset of the most recent phase of salt flow to this time (Fig. 9). This is approximately synchronous with the first episode of fluid expulsion from the pipe trails. Cumulative heave along the eastern margin of the Levant Basin varies by several kilometres and the average cumulative heave in the South Levant Basin ( 5600 m; from Fig. 6 in Cartwright and Jackson, 2008) is significantly greater than that of the North Levant Basin ( 2750 m; Fig. 8).

Cumulative heave of $3.9 \mathrm{~km}$ is measured from the extensional domain in line with the orientation of the Oceanus pipe trail, from which a comparable cumulative strain of 3.4 $\mathrm{km}$ was measured. Cumulative strain recorded by the Saida-Tyr fluid escape ranges from c. $5.4-8 \mathrm{~km}$. The nearest cumulative heave measurement from the extensional domain projected in line with the orientation of the Saida-Tyr pockmarks is c. $5200 \mathrm{~m}$ (Fig. 8). This is comparable to the lower cumulative strain measurements above the Saida-Tyr Structure but significantly lower than the largest recorded measurements.

\section{Discussion}

Through mapping of linearly distributed fluid escape pipes and pockmarks, evidence is presented here for multi-episode cross-evaporitic fluid expulsion, focused above presalt anticlines (Fig. 4 \& Fig. 6). The linear pockmark trails interpreted above the SaidaTyr Structure (Fig. 6) are important as they validate the novel method developed by Cartwright et al. (2018) of using fluid escape pipes as natural strain markers representing the kinematics of a salt layer deforming under gravity. The discovery of 
an additional 4 calibration points for the deforming salt layer provides an opportunity to assess the three-dimensional kinematics, albeit of a fairly small area of a much larger salt layer, and also to assess how the localised flow regime fits into the regional context and the drivers for salt tectonics.

\subsection{Salt flow direction}

Cartwright et al. (2018) demonstrated that the orientation of the pockmark trail above the Oceanus Structure constrains the cumulative flow direction of the salt layer at a single point within the basin. The addition of another 4 calibration points confirms the previously identified NW flow direction, and extends this over a distance of 40-50 km, along a critical region of the basin margin. Moreover, the NW flow direction matches the independent kinematic constraints for salt flow direction that can be obtained from the strike of the growth faults in the updip extensional domain, the small post-salt folds in the overburden in the contractional domain and the reflection dip direction in ramp syncline basins above the NW flank of the pre-salt folds (Allen et al., 2016, Cartwright et al., 2018, Pichel et al., 2018). This recent phase of gravity driven deformation is predominantly governed by marginal uplift, with gravitational loading presenting less of a controlling factor on salt flow, in contrast to the South Levant Basin where loading of the Nile Delta dominates. (Gradmann et al., 2005, Netzeband et al., 2006, Cartwright and Jackson, 2008, Allen et al., 2016, Feng et al., 2017). Located at the transition between translational and contractional domains (Fig. 1B) the pipe trails are ideally located to record the basinward flow of the salt, and provide a robust confirmation of the flow indicators derived from the overburden deformation. Furthermore, the minimal variation in flow direction between the pockmark trails above the Saida-Tyr Structure (Fig. 6D) demonstrates unidirectional flow over a distance of 6-7 km. Contrasting salt 
flow directions are expected in the South Levant Basin where variation in the orientation of the basin margins result in changes in basinward flow direction and gravitational loading from the Nile Delta exerts a greater influence (Cartwright and Jackson, 2008, Allen et al., 2016).

\subsection{Salt flow in $3 D$}

The proximity of the four pipe trails above the Saida-Tyr Structure provides several closely spaced kinematic indicators and this allows us to examine the average flow velocity at the local scale in the salt layer, in an area of the basin with a seemingly simple boundary condition of marginal tilting (Fig. 11). The flow within this part of the salt layer varies dramatically over a small lateral distance, suggesting perhaps that there are 'streams' of salt flowing at an anomalously high velocity compared to neighbouring portions of the layer (Dooley et al., 2016, Dooley et al., 2018), analogously perhaps to ice streams within ice sheets (Swithinbank, 1954). By making an assumption that the velocity for each trail has not varied through time, reference lines for time increments can be reconstructed for this part of the salt layer, and give an impression of accentuated flow in the region of ST3 (Fig. 11).

Comparison of the pipe trail lengths (from the fold crest) for the Oceanus and SaidaTyr Structures shows that the latter are 2-3 times longer than the former. Again, this is suggestive of local velocity variations, but on a scale of $10 \mathrm{~s}$ of $\mathrm{km}$ rather than a few $\mathrm{km}$ (Figs. 3A, 3B \& 11; Table 1). One possible explanation for this variation is the local impact that growth of the folds and contrasts in structural relief at the BES and in the thickness of the salt above the pre-salt folds have on flow in the salt layer. A decrease in the thickness of the salt above the pre-salt folds will have resulted in convergence of the streamlines, acceleration in the flow velocity and salt flux variations (Dooley et al., 
2016, Dooley et al., 2018, Pichel et al., 2018, Pichel et al., 2019). The salt flowing over the Sadia-Tyr Plateau (Fig. 5A) decreases to as little as less than half the thickness $(\sim 570 \mathrm{~m})$ of the salt at the Oceanus Structure ( 1200 m) (Fig. 3C). Once crossing the NW margin the Saida-Tyr Structure the salt increased to a thickness of $>1 \mathrm{~km}$ (Fig. 5A). Hence it is conceivable that this contrast in salt layer thickness across the actively growing fold led to a local acceleration of flow, as recorded downstream in the fluid escape pipe trail. Salt flow velocity is likely to have increased above the Oceanus Structure as well but not to the same degree as above the Saida-Tyr Structure due to the smaller amplitude of the fold as the BES and greater thickness of the salt above the fold.

Given that base-salt structural relief has a significant impact on salt flow and deformation patterns in the salt (Maillard et al., 2003, Dooley et al., 2016, Dooley et al., 2018, Pichel et al., 2018, M. Pichel et al., 2019), it is also possible that the local changes in base salt geometry and salt thickness along strike of the Saida-Tyr Structure play an important role in local salt velocity variation (Fig. 5). Where relief at the BES along the strike of the fold is greatest and the overlying salt is at its thinnest (Fig. 5), there will be increased convergence of streamlines in the flowing salt, resulting in locally greater salt flow velocities (Dooley and Hudec, 2016). The result is changes in flow velocity along the strike of the fold as relief at the BES and salt thickness varies, which is reflected in the planform geometry of the pipe trails (Fig. 11).

\subsection{Timing of salt deformation}

Previous studies in the Levant Basin have argued that the onset of growth fault development within the extensional domain of the basin dates the onset of the latest episode of salt flow. Cartwright and Jackson (2008) showed that the onset of growth 
faulting within the South Levant Basin was diachronous, starting as early as the Mid Pliocene along some parts of the extensional belt and as late as the early Pleistocene in others. A similar timing is recorded within the North Levant Basin, with minimal extension during the Pliocene and the main phase of growth post $1.8 \mathrm{Ma}( \pm 0.3 \mathrm{Ma})$ (Fig. 9). The initiation of the main phase of salt flow and growth fault development at the basin margin was therefore approximately synchronous with the onset of fluid expulsion in the five pipe trails. This implies that the pipe trails have recorded the complete flow history of the deforming salt from the Late Pliocene to the present day. The synchroneity in the timing of the onset of the fluid expulsion and the onset of the updip extension raises an interesting question as to whether there might be a more general connection between the fluid pressure regime and the drivers for salt tectonics in the North Levant Basin. The strong correlation in the timing of the first expulsion episode in each pipe trail means that the critical pressure for seal failure was met at the same time in each pressure cell (Moss et al., 2012). The magnitude of the overpressure required to form the fluid escape pipes is not known, but most probably was sufficient to exceed the hydraulic fracturing condition within the pre-salt and salt sections and hence must have been close to lithostatic pressure (Cartwright et al., 2018). The likeliest source of overpressure and fluids (pore water and methane) feeding these fluid escape features are Oligo-Miocene sandstones, analogous to the Lower Miocene 'Tamar' sands, found merely $60 \mathrm{~km}$ southeast of this 3D seismic survey (Needham et al., 2017).

Possible mechanisms for generating and recharging the required overpressures include gas generation and the buoyancy of a gas column, tectonic compression and eustatic fluctuations (Osborne and Swarbrick, 1997). Loading and unloading during the MSC may have also played a role in overpressuring, similar to other fluid flow features in the Eastern Mediterranean (Bertoni and Cartwright, 2015, Al-Balushi et al., 2016, Kirkham 
et al., 2018a). However, the overpressuring mechanisms driving the fluid flow features described here are currently poorly understood and require further investigation.

\subsection{Salt flow and cumulative strain}

The flow regime in salt basins where gravitational processes drive deformation has been modelled within the extensional domain as either a Poiseuille or combined PoiseuilleCouette, with a Couette flow regime in the contractional domain (Gemmer et al., 2004, Albertz and Ings, 2012, Quirk et al., 2012). The connection of the top of the deformed fluid escape pipes in the Messinian Evaporite Unit with the overburden beneath the oldest pockmark demonstrates that the salt and its overburden were fully coupled during the Pliocene to Recent. This implies that the growth faults in the extensional domain formed by the salt carrying the overburden during basinward flow from the basin margin (Quirk et al., 2012). Cumulative heave measurements, therefore, record the full flow distance of the top of the salt in the extensional domain during the recent phase of salt deformation. This argues against a purely Poiseuille Flow within the extensional domain otherwise it would be very difficult for the growth faults in the overburden to detach within the salt.

The flow regime in the salt within the translational-contractional domain during this phase of deformation, contrasts with the extensional domain in that it deforms by purely Couette Flow, with the full flow distance of the top of the salt recorded by the cumulative strain of the pipe trails. As the top of the salt and its overburden are coupled it might perhaps be expected that the flow distance of the top salt and overburden would be significantly greater in the contractional domain with a dominant Couette Flow than the extensional with a combined Poiseuille/Couette flow. However, similar values are recorded for cumulative strain and cumulative heave (Fig. 12). Some cumulative strain 
values recorded from the pipe trails above the Saida-Tyr Structure do exceed those of the cumulative strain at the margins. However, this can be explained in part by converging streamlines, as discussed above. It is therefore remarkable that despite contrasting flow regimes, the cumulative heave in the extensional domain and cumulative flow distance in the deeper basin are approximately in balance (Fig. 12) and this has profound implications for our understanding of the transition of flow regimes and balancing of salt flow between extensional and contractional domains.

\section{Conclusions}

1. Through seismic interpretation we employ a novel method of using fluid escape pipes that bypass the thick Messinian Evaporites in the Eastern Mediterranean as a tool for direct calibration of the kinematics of a deforming salt layer in 3D.

2. Multi-episode cross-evaporitic seepage and expulsion is demonstrated by 5 linear trails of pockmarks at the upper terminus of fluid escape pipes, which root to prominent pre-salt anticlines.

3. The fluid escape pipes have been deformed in the salt and the pockmarks in the Pliocene to Recent offset from above the crest of the pre-salt anticline by the flow of the salt.

4. The pipe trails record a dominantly NW basinward flow direction in the North Levant Basin, away from eastern margin.

5. The onset of fluid expulsion and the main phase of growth fault development in the extensional domain are approximately synchronous. The pipe trails, therefore, record the kinematics of the deforming salt layer throughout the most recent phase of its deformation since the MSC. 
6. Closely spaced pockmark trails above the Saida-Tyr Structure demonstrate unidirectional flow over distances of few $\mathrm{km}$.

7. Variability in base-salt relief and salt thickness over pre-salt folds causes localised variation in streamline convergence in the salt flowing over the fold. This results in changes in salt flow velocity along the strike of the fold of 2-4 $( \pm 0.3) \mathrm{mm} / \mathrm{yr}$.

8. A Couette flow regime through the salt and variations in cumulative strain and flow velocity spatially reveal the 3D kinematics of the deforming salt layer in the deep basin.

9. Cumulative heave in the extensional domain and cumulative strain in the contractional domain are balanced.

\section{Acknowledgments}

We are grateful to the editor Dario Civile and reviewers Leonardo Pichel and Ramadan

Ghalayini for their insightful comments that helped improve the manuscript. We would like to thank Spectrum for provision of the seismic data used in this research and Schlumberger for the seismic interpretation software used.

\section{References}

- $\quad$ Al-Balushi, A. N., Neumaier, M., Fraser, A. J. \& Jackson, C. A. 2016. The impact of the Messinian salinity crisis on the petroleum system of the Eastern Mediterranean: a critical assessment using 2D petroleum system modelling. Petroleum Geoscience, 22, 357-379.

- $\quad$ Albertz, M. \& Ings, S. J. 2012. Some consequences of mechanical stratification in basin-scale numerical models of passive-margin salt tectonics. Geological Society, London, Special Publications, 363, 303-330.

- $\quad$ Allen, H., Jackson, C. a.-L. \& Fraser, A. J. 2016. Gravity-driven deformation of a youthful saline giant: the interplay between gliding and spreading in the Messinian basins of the Eastern Mediterranean. Petroleum Geoscience, 22, 340-356.

- $\quad$ Bar, O., Zilberman, E., Feinstein, S., Calvo, R. \& Gvirtzman, Z. 2016. The uplift history of the Arabian Plateau as inferred from geomorphologic analysis of its northwestern edge. Tectonophysics, 671, 9-23. 
- $\quad$ Barbieri, M., Castorina, F., Colalongo, M. L., Pasini, G. \& Vaiani, S. C. 1998. Worldwide correlation of the Pliocene/Pleistocene GSSP at Vrica (Southern Italy) confirmed by strontium isotope stratigraphy. Newsletters on Stratigraphy, 177-187.

- $\quad$ Bertoni, C. 2006. 3D tectonostratigraphic analysis of the Messinian evaporites in the Levant Basin, Eastern Mediterranean, Cardiff University (United Kingdom).

- $\quad$ Bertoni, C. \& Cartwright, J. 2007. Major erosion at the end of the Messinian Salinity Crisis: evidence from the Levant Basin, Eastern Mediterranean. Basin Research, 19, 1-18.

- $\quad$ Bertoni, C. \& Cartwright, J. 2015. Messinian evaporites and fluid flow. Marine and Petroleum Geology, 66, 165-176.

- $\quad$ Bertoni, C. \& Cartwright, J. A. 2006. Controls on the basinwide architecture of late Miocene (Messinian) evaporites on the Levant margin (Eastern Mediterranean). Sedimentary Geology, 188, 93-114.

- $\quad$ Bertoni, C., Kirkham, C., Cartwright, J., Hodgson, N. \& Rodriguez, K. 2017. Seismic indicators of focused fluid flow and cross-evaporitic seepage in the Eastern Mediterranean. Marine and Petroleum Geology, 88, 472-488.

- $\quad$ Brown, A. R. 2011. Interpretation of three-dimensional seismic data, Society of Exploration Geophysicists and American Association of Petroleum.

- $\quad$ Brun, J.-P. \& Fort, X. 2011. Salt tectonics at passive margins: Geology versus models. Marine and Petroleum Geology, 28, 1123-1145.

- $\quad$ Cartwright, J., Kirkham, C., Bertoni, C., Hodgson, N. \& Rodriguez, K. 2018. Direct calibration of salt sheet kinematics during gravity-driven deformation. Geology. Cartwright, J. \& Santamarina, C. 2015. Seismic characteristics of fluid escape pipes in sedimentary basins: implications for pipe genesis. Marine and Petroleum Geology, 65, 126140.

- $\quad$ Cartwright, J. A. \& Jackson, M. 2008. Initiation of gravitational collapse of an evaporite basin margin: The Messinian saline giant, Levant Basin, eastern Mediterranean. Geological Society of America Bulletin, 120, 399-413.

- $\quad$ Catalano, R., Di Stefano, E., Sulli, A., Vitale, F. P., Infuso, S. \& Vail, P. R. 1998. Sequences and Systems Tracts Calibrated by High Resolution Bio-Chronostratigraphy: The Central Mediterranean Plio-Pleistocene Record.

- $\quad$ Davison, I., Alsop, I. \& Blundell, D. 1996. Salt tectonics: some aspects of deformation mechanics. Geological Society, London, Special Publications, 100, 1-10.

- $\quad$ Dooley, T. P. \& Hudec, M. R. 2016. The effects of base-salt relief on salt flow and suprasalt deformation patterns - Part 2: Application to the eastern Gulf of Mexico. Interpretation, 5, SD25-SD38.

- $\quad$ Dooley, T. P., Hudec, M. R., Carruthers, D., Jackson, M. P. \& Luo, G. 2016. The effects of base-salt relief on salt flow and suprasalt deformation patterns-Part 1: Flow across simple steps in the base of salt. Interpretation, 5, SD1-SD23.

- $\quad$ Dooley, T. P., Hudec, M. R., Pichel, L. M. \& Jackson, M. P. 2018. The impact of base-salt relief on salt flow and suprasalt deformation patterns at the autochthonous, paraautochthonous and allochthonous level: insights from physical models. Geological Society, London, Special Publications, 476, SP476. 13.

- $\quad$ Druckman, Y., Buchbinder, B., Martinotti, G., Tov, R. S. \& Aharon, P. 1995. The buried Afiq Canyon (eastern Mediterranean, Israel): a case study of a Tertiary submarine canyon exposed in Late Messinian times. Marine Geology, 123, 167-185.

- $\quad$ Feng, Y. E., Steinberg, J. \& Reshef, M. 2017. Intra-salt deformation: Implications for the evolution of the Messinian evaporites in the Levant Basin, eastern Mediterranean. Marine and Petroleum Geology, 88, 251-267.

- $\quad$ Feng, Y. E., Yankelzon, A., Steinberg, J. \& Reshef, M. 2016. Lithology and characteristics of the Messinian evaporite sequence of the deep Levant Basin, eastern Mediterranean. Marine Geology, 376, 118-131.

- $\quad$ Gardosh, M. A. \& Druckman, Y. 2006. Seismic stratigraphy, structure and tectonic evolution of the Levantine Basin, offshore Israel. Geological Society, London, Special Publications, 260, 201-227.

- $\quad$ Garfunkel, Z. 1984. Large-scale submarine rotational slumps and growth faults in the eastern Mediterranean. Marine Geology, 55, 305-324.

- $\quad$ Gemmer, L., Ings, S. J., Medvedev, S. \& Beaumont, C. 2004. Salt tectonics driven by differential sediment loading: stability analysis and finite-element experiments. Basin Research, 16, 199-218. 
- $\quad$ Ghalayini, R., Daniel, J. M., Homberg, C., Nader, F. H. \& Comstock, J. E. 2014. Impact of Cenozoic strike-slip tectonics on the evolution of the northern Levant Basin (offshore Lebanon). Tectonics, 33, 2121-2142.

- $\quad$ Ghalayini, R., Homberg, C., Daniel, J. \& Nader, F. 2017. Growth of layer-bound normal faults under a regional anisotropic stress field. Geological Society, London, Special Publications, 439, 57-78.

- $\quad$ Ghalayini, R., Nader, F., Bou Daher, S., Hawie, N. \& Chbat, W. 2018. Petroleum systems of Lebanon: An update and review. Journal of Petroleum Geology, 41, 189-214.

- $\quad$ Gradmann, S., Hübscher, C., Ben-Avraham, Z., Gajewski, D. \& Netzeband, G. 2005. Salt tectonics off northern Israel. Marine and Petroleum Geology, 22, 597-611.

- $\quad$ Gvirtzman, Z., Manzi, V., Calvo, R., Gavrieli, I., Gennari, R., Lugli, S., Reghizzi, M. \& Roveri, M. 2017. Intra-Messinian truncation surface in the Levant Basin explained by subaqueous dissolution. Geology, 45, 915-918.

- $\quad$ Gvirtzman, Z., Reshef, M., Buch-Leviatan, O. \& Ben-Avraham, Z. 2013. Intense salt deformation in the Levant Basin in the middle of the Messinian Salinity Crisis. Earth and Planetary Science Letters, 379, 108-119.

- $\quad$ Hall, J., Calon, T., Aksu, A. \& Meade, S. 2005. Structural evolution of the Latakia Ridge and Cyprus Basin at the front of the Cyprus Arc, eastern Mediterranean Sea. Marine Geology, 221, 261-297.

- $\quad$ Hawie, N., Gorini, C., Deschamps, R., Nader, F. H., Montadert, L., Granjeon, D. \& Baudin, F. 2013. Tectono-stratigraphic evolution of the northern Levant Basin (offshore Lebanon). Marine and Petroleum Geology, 48, 392-410.

- $\quad$ Ismail-Zadeh, A., Tsepelev, I., Talbot, C. \& Korotkii, A. 2004. Three-dimensional forward and backward modelling of diapirism: numerical approach and its applicability to the evolution of salt structures in the Pricaspian basin. Tectonophysics, 387, 81-103.

- Jackson, M. P. \& Hudec, M. R. 2005. Stratigraphic record of translation down ramps in a passive-margin salt detachment. Journal of Structural Geology, 27, 889-911.

- Jackson, M. P. \& Hudec, M. R. 2017. Salt tectonics: Principles and practice, Cambridge University Press.

- $\quad$ Judd, A. \& Hovland, M. 2009. Seabed fluid flow: the impact on geology, biology and the marine environment, Cambridge University Press.

- $\quad$ Kaus, B. J. \& Podladchikov, Y. Y. 2001. Forward and reverse modeling of the threedimensional viscous Rayleigh-Taylor instability. Geophysical Research Letters, 28, 10951098.

- $\quad$ Kehle, R. O. 1988. The origin of salt structures. In: Schreiber, C.B. (Ed.), Evaporites and hydrocarbons, Columbia Univ. Press, NY.

- $\quad$ Kirkham, C., Cartwright, J., Hermanrud, C. \& Jebsen, C. 2018a. The formation of giant clastic extrusions at the end of the Messinian Salinity Crisis. Earth and Planetary Science Letters, 482, 434-445.

- $\quad$ Kirkham, C., Cartwright, J., Hermanrud, C. \& Jebsen, C. 2018b. The genesis of mud volcano conduits through thick evaporite sequences. Basin Research, 30, 217-236.

- $\quad$ Kosi, W., Tari, G., Nader, F. H., Skiple, C., Trudgill, B. \& Lazar, D. 2012. Structural analogy between the "piano key faults" of deep-water Lebanon and the extensional faults of the Canyonlands grabens, Utah, United States. The Leading Edge, 31, 824-830.

- Lofi, J. 2018. Seismic Atlas of the Messinian Salinity Crisis markers in the Mediterranean Sea-Volume 2. Société Géologique de France.

- $\quad$ Lofi, J., Déverchère, J., Gaullier, V., Gillet, H., Gorini, C., Guennoc, P., Loncke, L., Maillard, A., Sage, F. \& Thinon, I. 2011. Seismic atlas of the Messinian Salinity Crisis markers in the Mediterranean and Black Seas, Société Géologique de France.

- $\quad$ Loncke, L., Gaullier, V., Mascle, J., Vendeville, B. \& Camera, L. 2006. The Nile deep-sea fan: an example of interacting sedimentation, salt tectonics, and inherited subsalt paleotopographic features. Marine and Petroleum Geology, 23, 297-315.

- $\quad$ Løseth, H., Gading, M. \& Wensaas, L. 2009. Hydrocarbon leakage interpreted on seismic data. Marine and Petroleum Geology, 26, 1304-1319.

M. Pichel, L., Finch, E. \& Gawthorpe, R. L. 2019. The Impact of Pre-Salt Rift Topography on Salt Tectonics: A Discrete-Element Modeling Approach. Tectonics, 38, 1466-1488.

- $\quad$ Maillard, A., Gaullier, V., Vendeville, B. C. \& Odonne, F. 2003. Influence of differential compaction above basement steps on salt tectonics in the Ligurian-Provençal Basin, northwest Mediterranean. Marine and Petroleum Geology, 20, 13-27. 

reversal of drainage systems in northern Israel: tectonic implications. Geomorphology, 28, 4359.

- $\quad$ Moss, J. \& Cartwright, J. 2010. 3D seismic expression of km-scale fluid escape pipes from offshore Namibia. Basin Research, 22, 481-501.

- $\quad$ Moss, J., Cartwright, J., Cartwright, A. \& Moore, R. 2012. The spatial pattern and drainage cell characteristics of a pockmark field, Nile Deep Sea Fan. Marine and Petroleum Geology, 35, 321-336.

- $\quad$ Mukherjee, S., Talbot, C. J. \& Koyi, H. A. 2010. Viscosity estimates of salt in the Hormuz and Namakdan salt diapirs, Persian Gulf. Geological Magazine, 147, 497-507.

- $\quad$ Nader, F. H. 2011. The petroleum prospectivity of Lebanon: an overview. Journal of Petroleum Geology, 34, 135-156.

- $\quad$ Nader, F. H., Inati, L., Ghalayini, R., Hawie, N. \& Daher, S. B. 2018. Key geological characteristics of the Saida-Tyr Platform along the eastern margin of the Levant Basin, offshore Lebanon: implications for hydrocarbon exploration. Oil \& Gas Science and Technology-Revue d'IFP Energies nouvelles, 73, 50.

- $\quad$ Needham, D. L., Pettingill, H. S. \& Christensen, C. J. 2017. The Tamar Giant Gas Field: Opening the Subsalt Miocene Gas Play in the Levant Basin. AAPG Memoir, 113, 223-256. - $\quad$ Netzeband, G., Hübscher, C. \& Gajewski, D. 2006. The structural evolution of the Messinian evaporites in the Levantine Basin. Marine Geology, 230, 249-273.

\section{- $\quad$ Osborne, M. J. \& Swarbrick, R. E. 1997. Mechanisms for generating overpressure in} sedimentary basins: A reevaluation. AAPG bulletin, 81, 1023-1041.

- $\quad$ Peel, F. J. 2014. The engines of gravity-driven movement on passive margins: Quantifying the relative contribution of spreading vs. gravity sliding mechanisms. Tectonophysics, 633, 126142.

- $\quad$ Pichel, L. M., Huuse, M., Redfern, J. \& Finch, E. 2019. The influence of base-salt relief, rift topography and regional events on salt tectonics offshore Morocco. Marine and Petroleum Geology, 103, 87-113.

- $\quad$ Pichel, L. M., Peel, F., Jackson, C. A. \& Huuse, M. 2018. Geometry and kinematics of saltdetached ramp syncline basins. Journal of Structural Geology, 115, 208-230.

- $\quad$ Quirk, D. G., Schødt, N., Lassen, B., Ings, S. J., Hsu, D., Hirsch, K. K. \& Von Nicolai, C. 2012. Salt tectonics on passive margins: examples from Santos, Campos and Kwanza basins. Geological Society, London, Special Publications, 363, 207-244.

- $\quad$ Reiche, S., Hübscher, C. \& Beitz, M. 2014. Fault-controlled evaporite deformation in the Levant Basin, Eastern Mediterranean. Marine Geology, 354, 53-68.

- $\quad$ Rio, D., Raffi, I. \& Backman, J. 1997. Calcareous nannofossil biochronology and the Pliocene-Pleistocene boundary. WORLD AND REGIONAL GEOLOGY, 63-78.

- $\quad$ Robertson, A., Dixon, J., Brown, S., Collins, A., Morris, A., Pickett, E., Sharp, I. \& Ustaömer, T. 1996. Alternative tectonic models for the Late Palaeozoic-Early Tertiary development of Tethys in the Eastern Mediterranean region. Geological Society, London, Special Publications, 105, 239-263.

- $\quad$ Rowan, M. G., Peel, F. J. \& Vendeville, B. C. 2004. Gravity-driven fold belts on passive margins. AAPG Memoir, 82, 157-182.

- $\quad$ Swithinbank, C. 1954. "Ice streams" 2. Polar record, 7, 185-186.

- $\quad$ Talbot, C. J. 1998. Extrusions of Hormuz salt in Iran. Geological Society, London, Special Publications, 143, 315-334.

- $\quad$ Urai, J., Schléder, Z., Spiers, C. \& Kukla, P. 2008. Flow and transport properties of salt rocks. Dynamics of complex intracontinental basins: The central European basin system, 277-290.

- $\quad$ Urai, J. \& Spiers, C. The effect of grain boundary water on deformation mechanisms and rheology of rocksalt during long-term deformation. Proc. 6th Conf. Mech. Beh. of Salt, 2007. 149-158.

- Walley, C. D. 1998. Some outstanding issues in the geology of Lebanon and their importance in the tectonic evolution of the Levantine region. Tectonophysics, 298, 37-62.

- $\quad$ Weinberger, R., Lyakhovsky, V., Baer, G. \& Begin, Z. 2006. Mechanical modeling and InSAR measurements of Mount Sedom uplift, Dead Sea basin: Implications for effective viscosity of rock salt. Geochemistry, Geophysics, Geosystems, 7. 

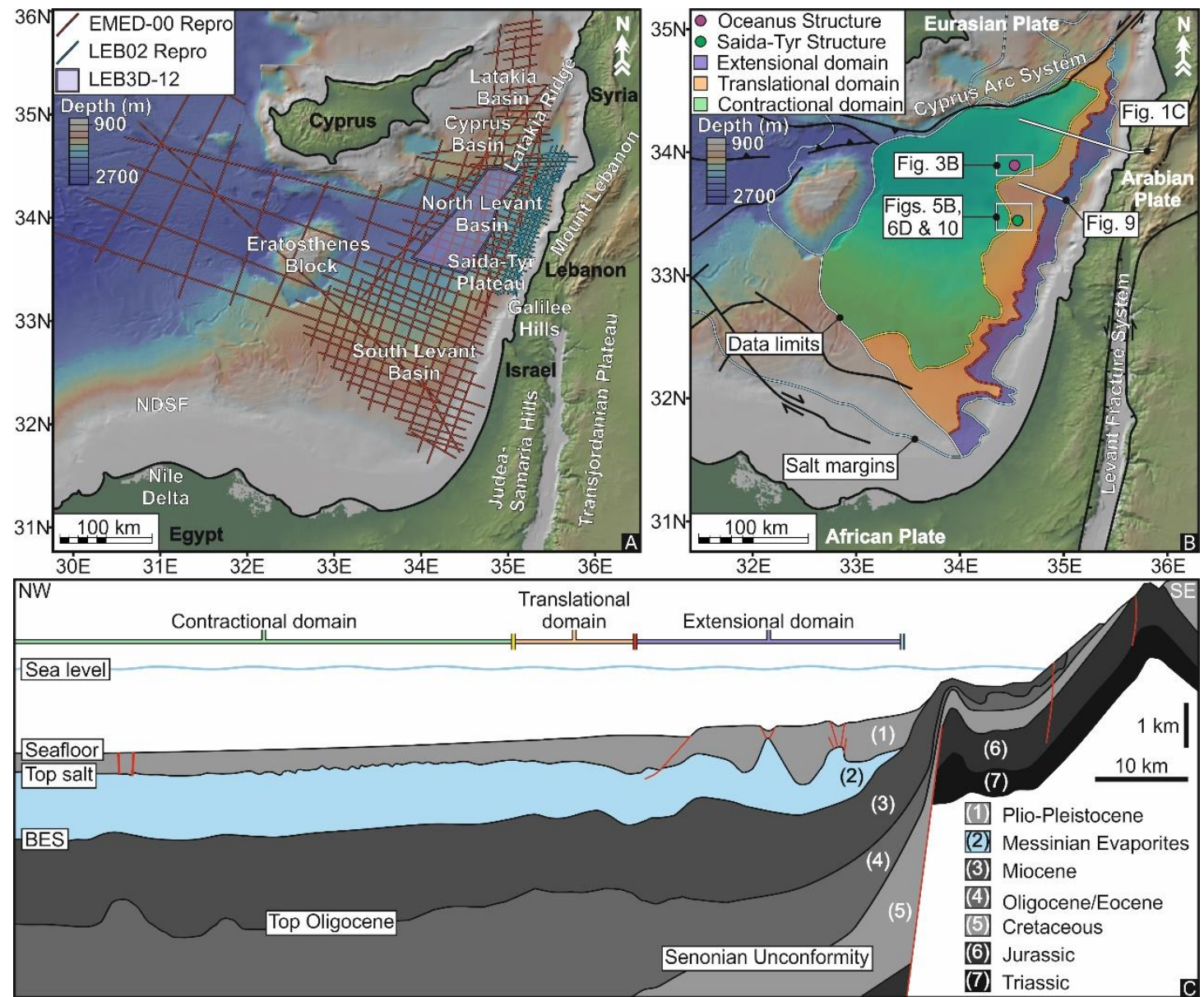

Figure 1. Regional setting. A: Bathymetric map in the Eastern Mediterranean with the location of the seismic data used in this study. NDSF - Nile Deep Sea Fan. B: A map of the study area showing the main tectonic elements, location of the Oceanus Structure and Saida Tyr Structure, and the extensional, translation and contractional domains of the salt basin. The salt margin is modified from Lofi et al., (2011). C: A cross-section extending from onshore Lebanon to the offshore in the

912 North Levant Basin, showing the main stratigraphy, uplifted structures onshore and extent of the 913 extensional, translational and contractional domains. Onshore modified from Nader (2011). BES

914 - Bottom erosional surface. 


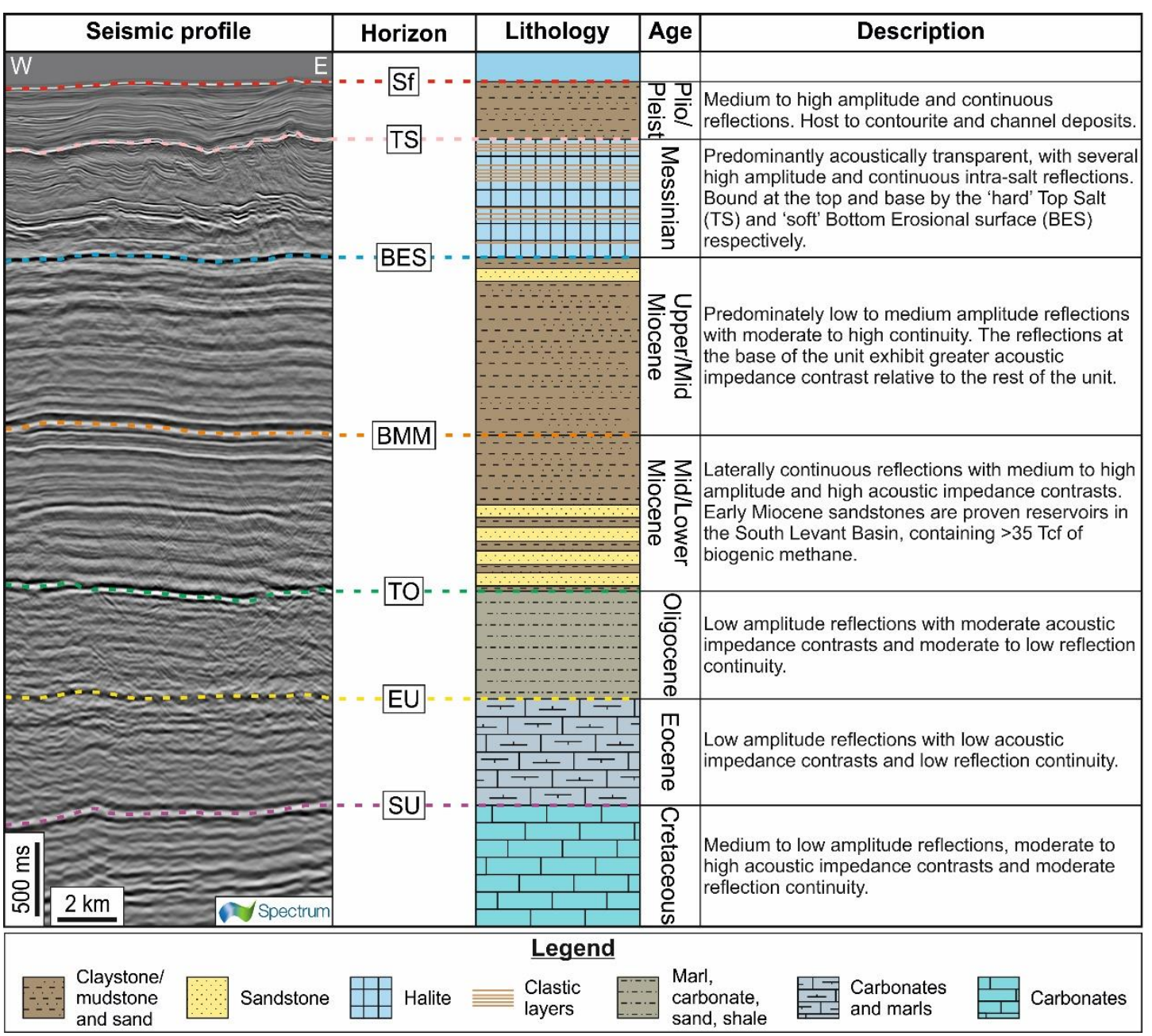

916 Figure 2. Stratigraphy of the Levant Basin (modified from Ghalayini et al. (2014), Gardosh and

917 Druckman (2006) and Karyna Rodriguez (2019, personal communication, 01 May). From left to

918 right, a seismic column with key marker horizons picked, a lithological column, the age of the

919 seismic units and a description of the seismic facies of each unit. Sf - seafloor; TS - Top Salt; BES

920 - Bottom Erosional Surface; BMM - Base Mid Miocene; TO - Top Oligocene; EU - Eocene

921 Unconformity; SU - Senonian Unconformity. 

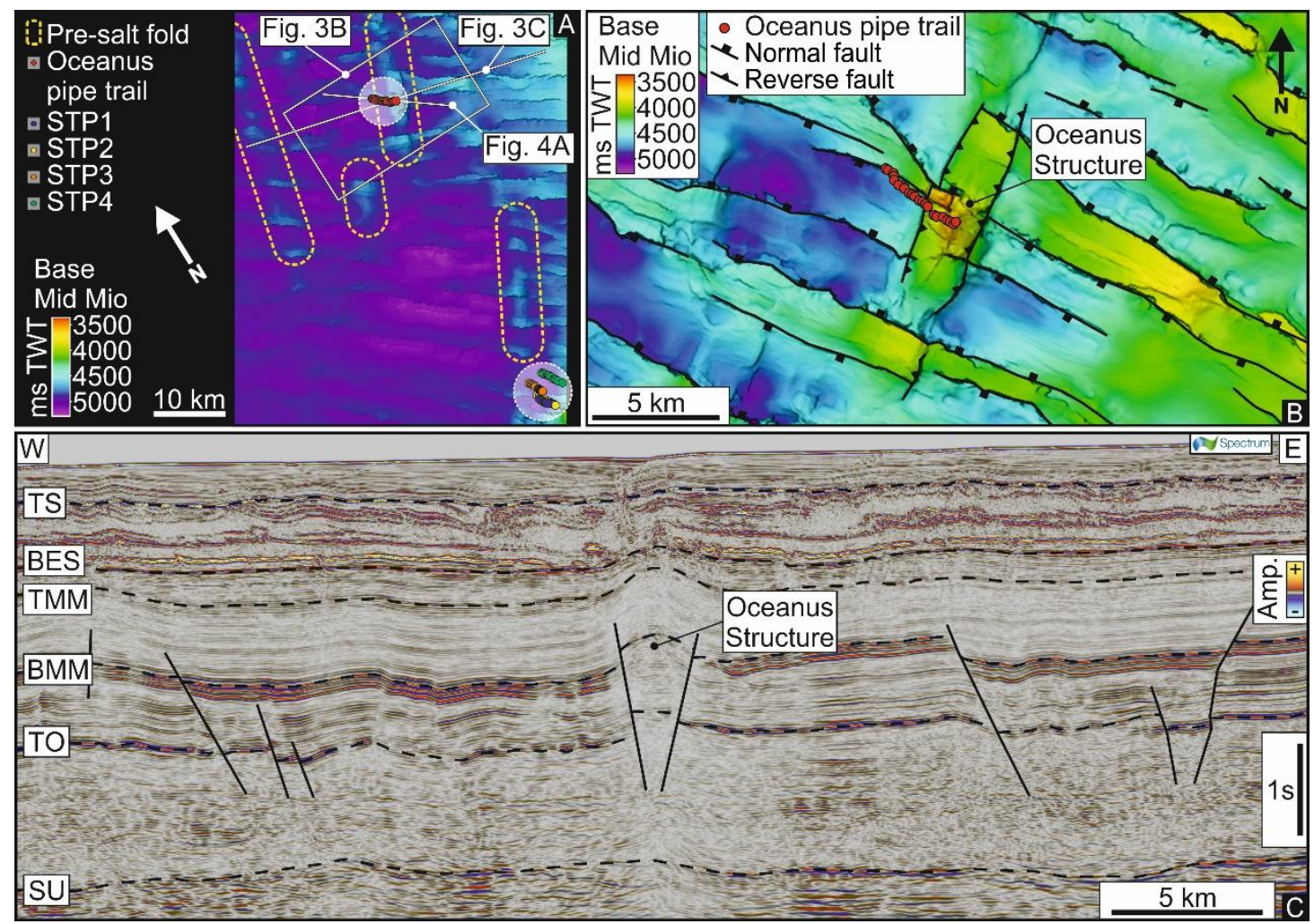

Figure 3. The Oceanus Structure. A: Base Mid Miocene map in the LEB3D seismic survey area, displaying numerous prominent NE-SW oriented pre-salt folds (outlined by yellow dashed lines).

The location of the Oceanus pipe trail and Saida-Tyr pipe trails are shown (highlighted by white dashed circle). B: Base Mid Miocene map highlighting the pre-salt fold of the Oceanus Structure, the overlying Oceanus pipe trail and the main structural lineament. C: Seismic cross-section through the crest of the Oceanus Structure showing syn-kinematic sedimentary growth onto the anticline from the Mid Miocene and the thick Messinian Evaporite Unit that overlies. TS - Top

933 salt; BES - Bottom erosional surface; TMM - Top Mid Miocene; BMM - Base Mid Miocene; TO

- Top Oligocene; EU - Eocene Unconformity; SU - Senonian Unconformity. 


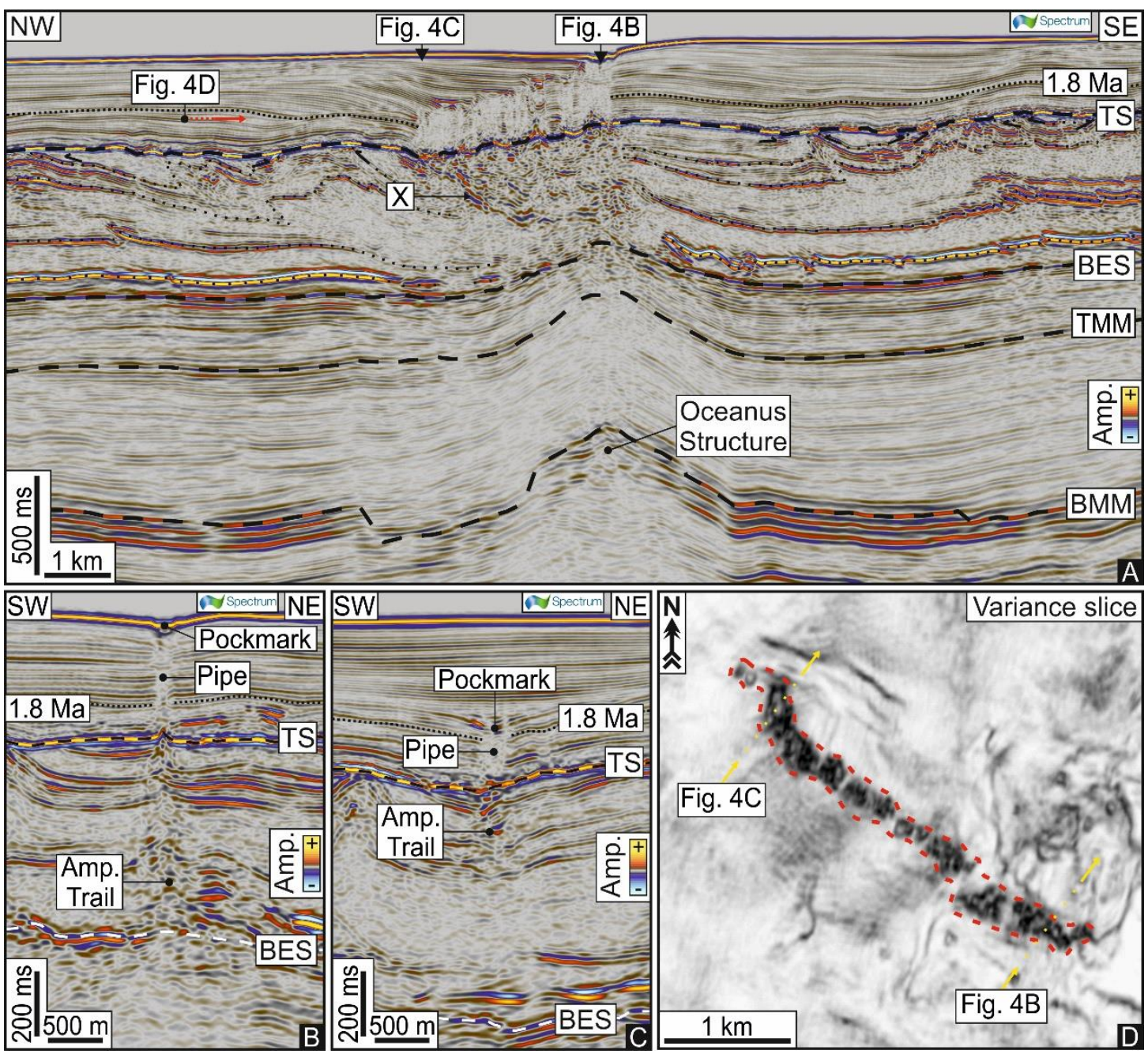

937 Figure 4. Fluid escape pipes deformed by salt flow. A: Seismic cross-section (see Fig. 3A for

938 location) through a linearly distributed trail (NW-SE) of fluid escape pipes located above the pre-

939 salt Oceanus Structure. A fluid escape pipe that has been deformed in the salt (X) extends from

940 beneath the most north-westerly pockmark to the crest of the fold at the BES (Bottom Erosional

941 surface. TES - Top salt; TMM - Top Mid Miocene; BMM - Base Mid Miocene B: Seismic cross-

942 section through the youngest fluid escape pipe with a pockmark at the present day seafloor. An

943 amplitude trail can be seen extending through the salt in line with the pockmark. This most recent

944 fluid escape pipe roots to the crest of the Oceanus Structure at the BES. C: Seismic cross-section

945 through the oldest fluid escape pipe and pockmark in the linear trail, showing an age of 1.7 Ma

$946 \quad( \pm 0.3 \mathrm{Ma})$. The pockmark is offset $3.4 \mathrm{~km}$ from the crest of the Oceanus Structure. D: A variance

947 slice through the linear trail of fluid escape pipes, displaying a NW-SE oriented trail of circular to

948 elliptical discontinuities (outlined by red dashed line) representing the planform of the pipes. 


\begin{tabular}{|c|c|c|c|c|c|c|c|}
\hline Name & $\begin{array}{l}\text { Number } \\
\text { of pipes }\end{array}$ & $\begin{array}{l}\text { Pockmarks } \\
\text { diameter } \\
\text { range }(\mathbf{m})\end{array}$ & $\begin{array}{l}\text { Pockmark } \\
\text { spacing } \\
\text { range }(\mathbf{m})\end{array}$ & $\begin{array}{l}\text { Distance from } \\
\text { oldest } \\
\text { pockmark to } \\
\text { fold crest (m) } \\
(+/-10 \%)\end{array}$ & $\begin{array}{l}\text { Age of first } \\
\text { pockmark } \\
\text { (Myrs; }( \pm 0.3 \\
\text { Ma) }\end{array}$ & $\begin{array}{l}\text { Average } \\
\text { orientation } \\
\text { in degrees }\left({ }^{\circ}\right)\end{array}$ & $\begin{array}{l}\text { Max flow } \\
\text { velocity } \\
(\mathbf{m m} / \mathbf{y r} ; \\
\pm 0.3 \\
\mathbf{m m} / \mathbf{y r})\end{array}$ \\
\hline $\begin{array}{l}\text { Oceanus } \\
\text { pipe trail }\end{array}$ & 21 & $58-254$ & $93-419$ & 3400 & 1.7 & $128-308$ & 2 \\
\hline STP 1 & 9 & $68-274$ & $60-625$ & 6634 & 1.7 & $151-331$ & 4 \\
\hline STP 2 & 14 & $52-155$ & $107-654$ & 6637 & 1.7 & $150-330$ & 4 \\
\hline STP 3 & 15 & $66-212$ & $46-303$ & 7981 & 1.7 & $152-332$ & 4 \\
\hline STP 4 & 12 & 64-172 & $30-514$ & 5412 & 1.7 & $148-328$ & 3 \\
\hline
\end{tabular}

951 Table 1. Statistics of fluid escape pipe and pockmark trails.

952

953

954

955

956

957

958

959

960

961

962

963

964

965

966

967

968

969

970

971

972 


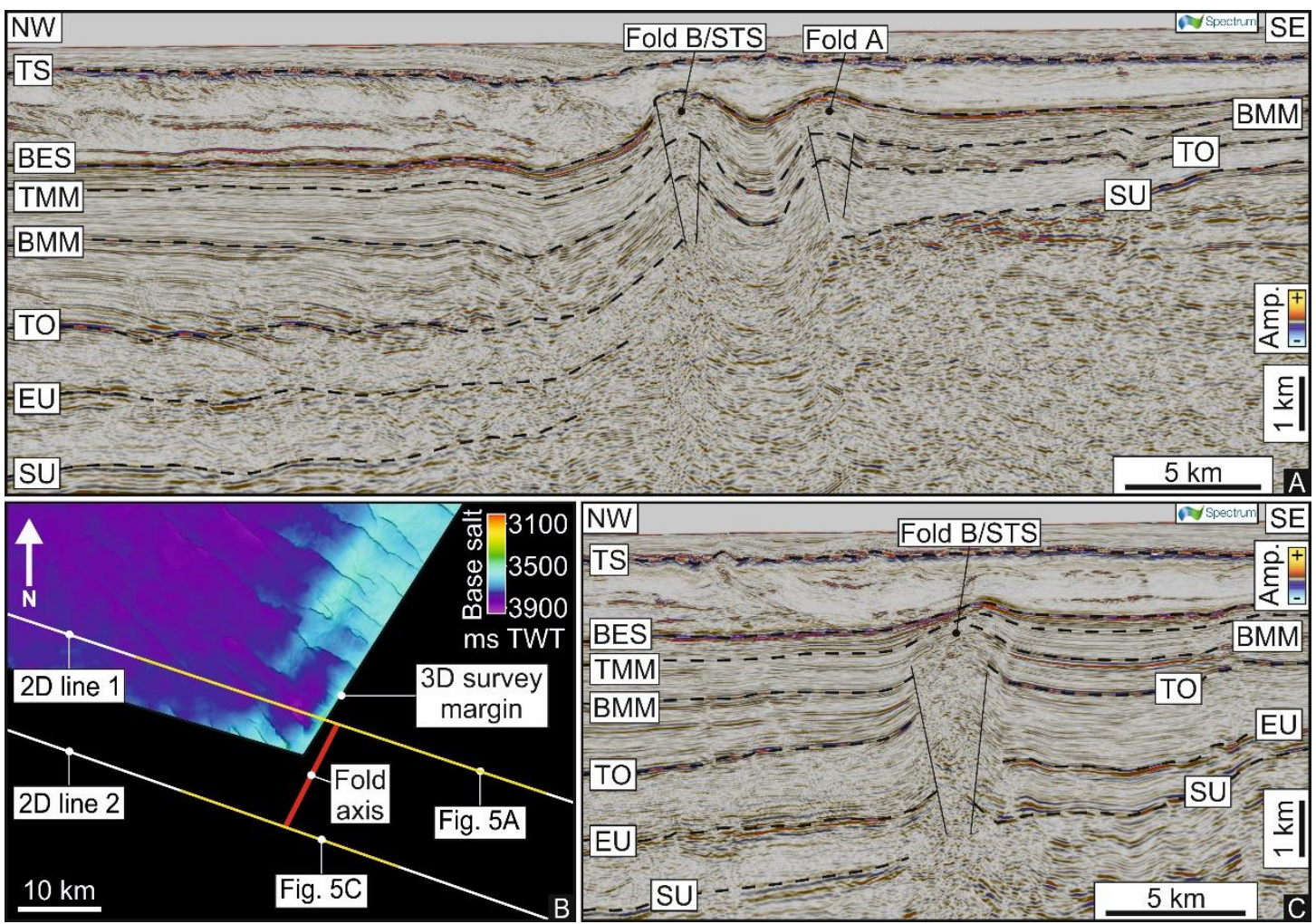

974 Figure 5. The Saida-Tyr Structure. A: Seismic cross-section (2D line 1) through the Sadia-Tyr

975 Structure (STS; Fold A). The fold has amplitude c. $>\mathbf{1 0 5 0} \mathbf{m}$ and significant variation in the 976 geometry of the BES (Bottom erosional surface) and the salts thickness over the fold. TS - Top salt; TMM - Top Mid Miocene; BMM - Base Mid Miocene; TO - Top Oligocene; EU - Eocene Unconformity; SU - Senonian Unconformity. B: Map of the BES at the SE margin of the 3D seismic survey, with the location of $2 D$ line $1 \& 2$ and the fold axis of the Saida-Tyr Structure interpolated from these 2D lines. C: Seismic cross-section (2D line 2) through the southern section of the SaidaTyr Structure, exhibiting less amplitude than in Fig. 5A and more moderate changes in the geometry of the BES and the thickness of the salt. 

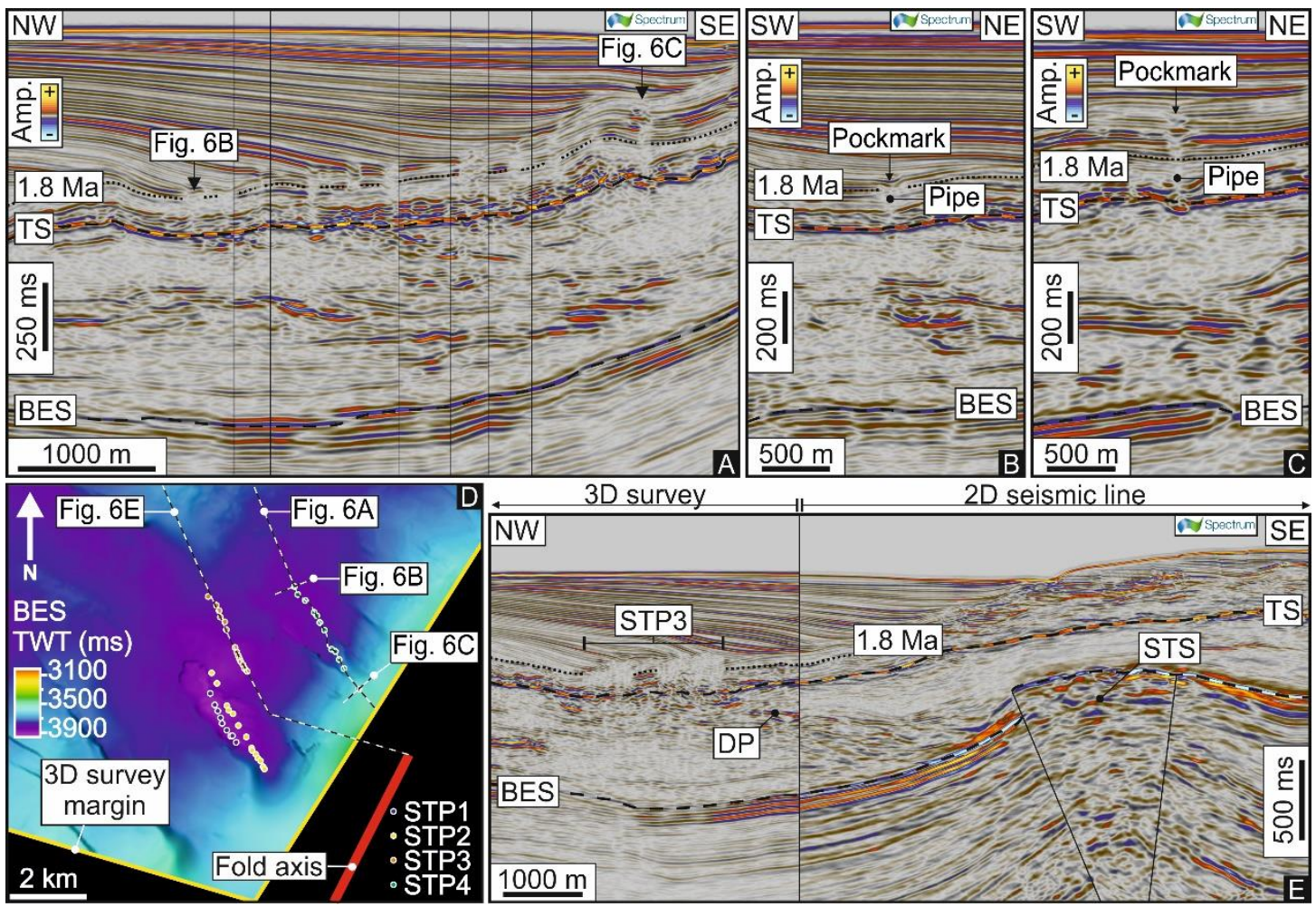

Figure 6. Saida-Tyr Structure fluid escape. A: Seismic cross-section through STP4 above the

Saida-Tyr Structure. B: Cross-section perpendicular to the strike of STP4, through the oldest pockmark in the trail, showing an age of $\sim 1.7 \mathrm{Ma}( \pm 0.3 \mathrm{Ma}) . \mathrm{C}$ : Cross-section perpendicular to the strike of STP4, through the youngest pockmark interpretable in the trail within the 3D seismic survey. D: A map of the BES (Bottom erosional surface) with the location of the fold axis of the Saida-Tyr Structure and the locations of STP1-4 lineally distributed NW-SE. E: Composite line using 3D seismic and 2D line 1 (see Fig. 5B) through part of STP3 toward the Saida-Tyr Structure 


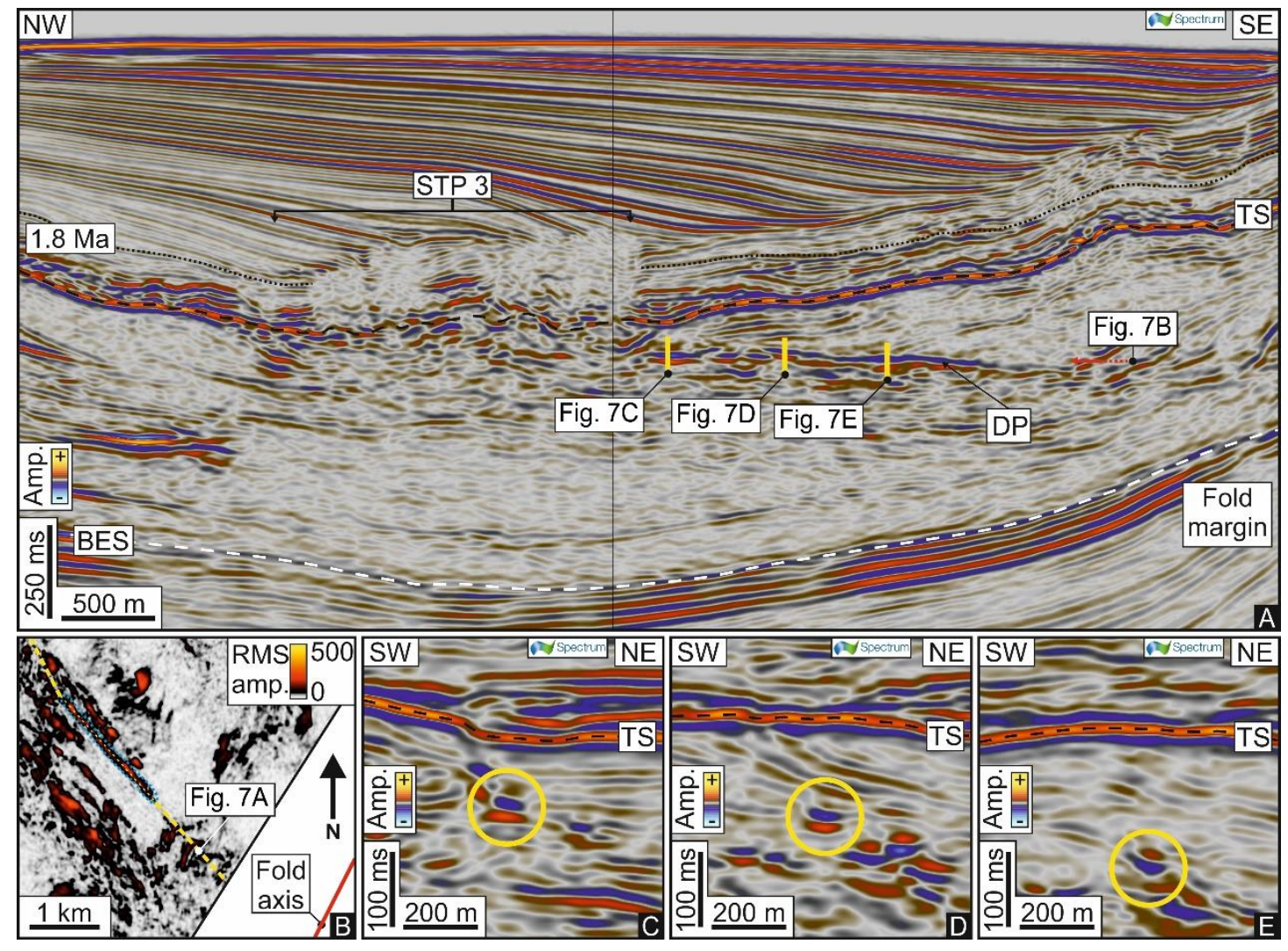

Figure 7. Deformed fluid escape pipe through salt. A: Seismic cross-section along strike of STP3 and its outermost deformed pipe (DP) in the salt. The deformed pipe has a 'soft' seismic response, extends from beneath the pockmark trail obliquely through the salt toward the Saida-Tyr Structure and is geometrically divergent to the other intra-salt reflection. B: RMS amplitude extraction that displays part of the deformed pipe in the salt as a localised and linear NW-SE oriented anomaly (highlighted by the blue dotted line) of higher amplitude than the hosting salt. C-E: Seismic cross-sections orthogonal to the strike of the deformed pipe. The cross-sections are distributed along strike of the deformed pipe, displaying it as a localised 'soft' anomaly, progressively increasing in depth through the salt. (TS - Top salt) 

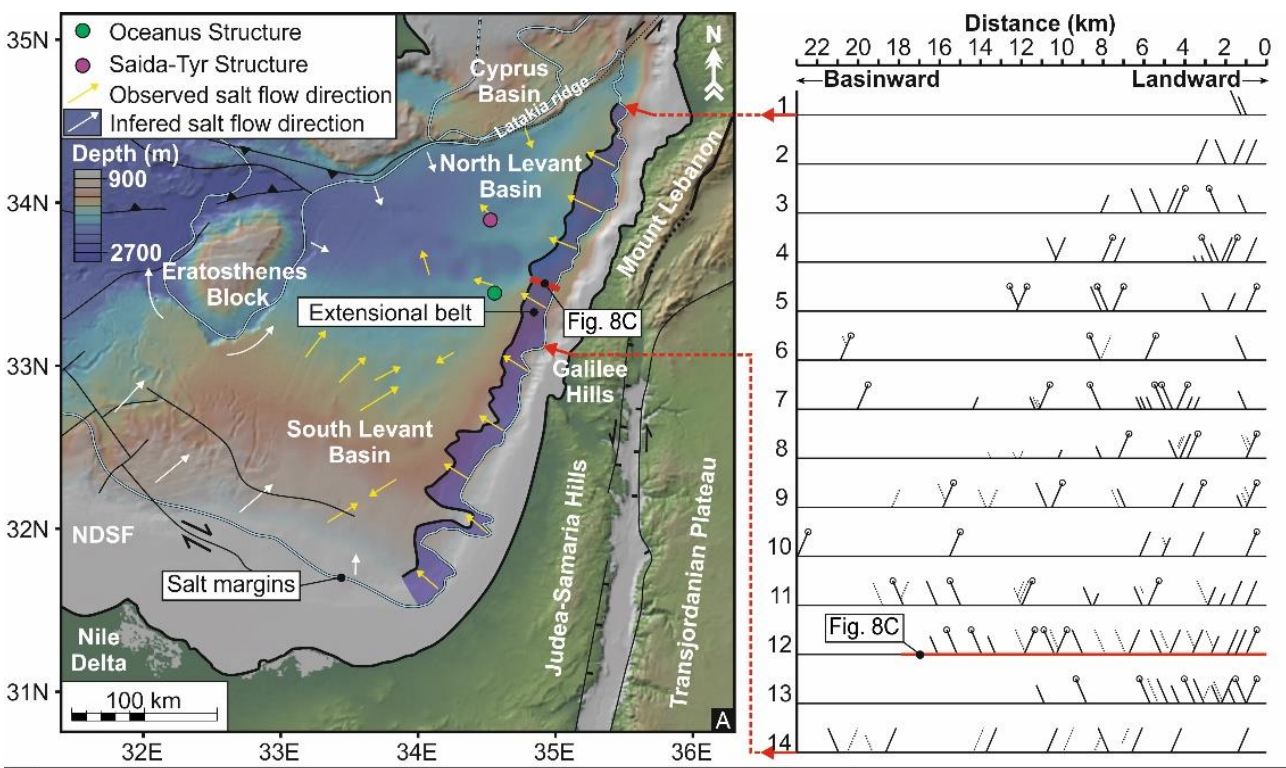

$33 \mathrm{E}$

$34 \mathrm{E}$

$35 \mathrm{E}$

$36 \mathrm{E}$
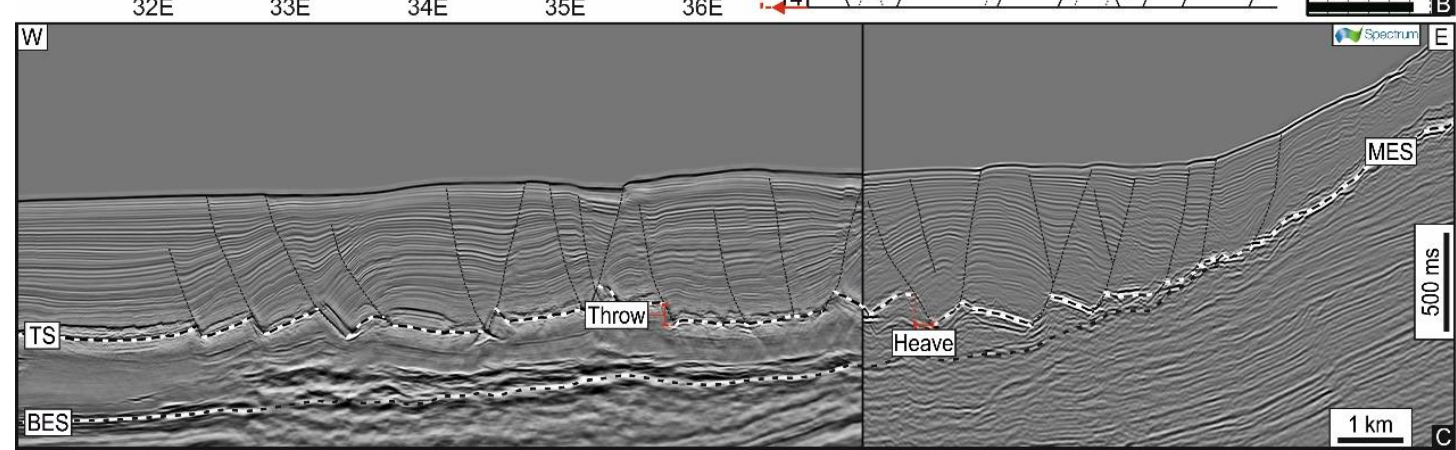

Figure 8. Salt flow and marginal extension in the Levant Basin. A: A bathymetric map with arrows overlain that represent the known and inferred salt flow directions from 2D and 3D seismic reflection data and published literature (Cartwright and Jackson, 2008; Allen et al., 2016; Feng et al., 2016). The extensional domain (blue fill) is parallel to the eastern margin showing a basinward salt flow direction. The salt margin is modified from Lofi et al., (2011). B: Fault data from 14 profiles that cross the extensional domain in the North Levant Basin (red arrows delimit the location of the profiles on the map) is recorded. Each profile displays the fault direction, fault spacing, whether the fault reaches the seafloor (circle at upper tip) and fault relative throw (dotted vs thick line for fault, for low vs high throw respectively). The graph (right) displays the cumulative heave for the faults in each profile. C: A composite seismic cross-section of profile 12 in Fig. $8 B$ through the extensional domain of the salt basin, showing an array of extension fault and how throw and heave measurements are recorded. TS - Top salt; BES - Bottom erosional surface; MES - Messinian erosional surface. 


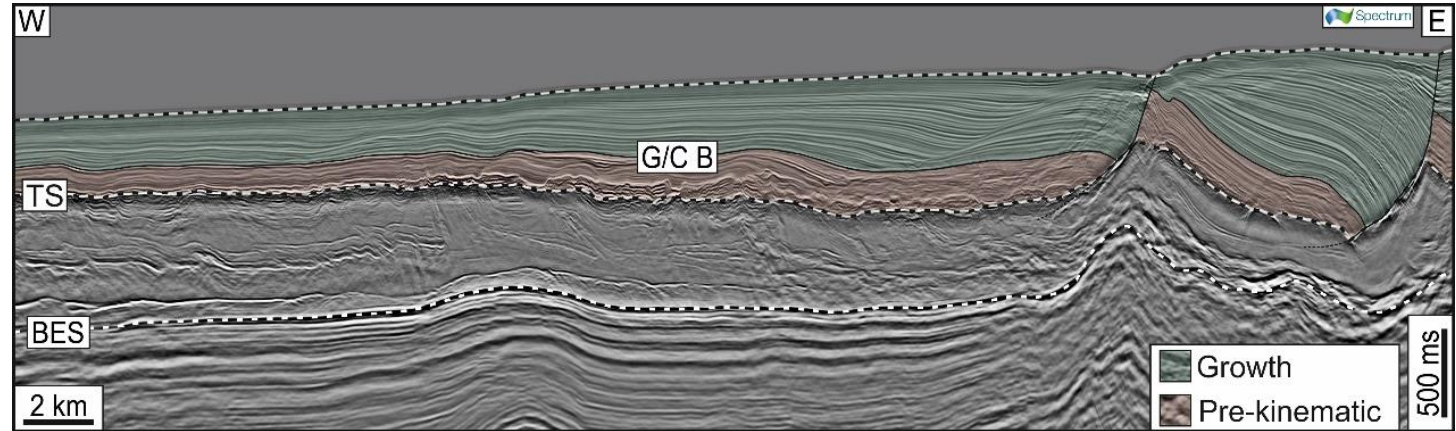

Figure 9. Calibration of the Gelasian/Calabrian Boundary (G/C B) to the extensional domain.

There is minimal growth over the extensional faults prior to Calabrian, with the majority of growth over the last 1.8 Ma ( $\pm 0.3 \mathrm{Ma})$. TS - Top salt; BES - Bottom erosional surface.

1028

1029

1030

1031

1032

1033

1034

1035

1036

1037

1038

1039

1040

1041

1042

1043

1044

1045

1046

1047 


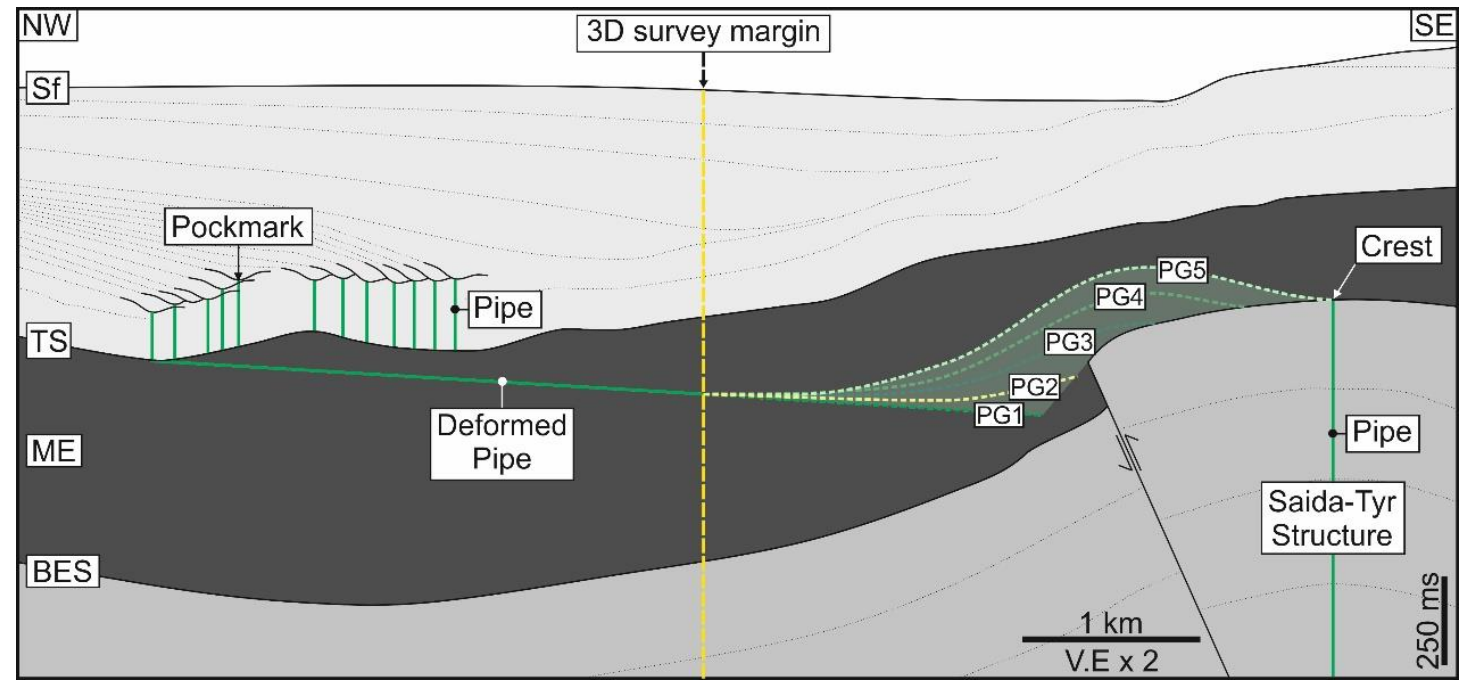

Figure 10. A schematic cross-section through the Saida-Tyr Structure and one of its overlying pipe trails. The deformed fluid escape pipe and its geometry is well imaged in the salt within the 3D seismic survey, but cannot be interpreted beyond the 3D survey margins. The uncertainty and range of potential permutations in pipe geometry (PG) are demonstrated by PG1-PG5. Sf Seafloor; TS - Top salt; ME - Messinian Evaporites; BES - Bottom Erosional Surface. 


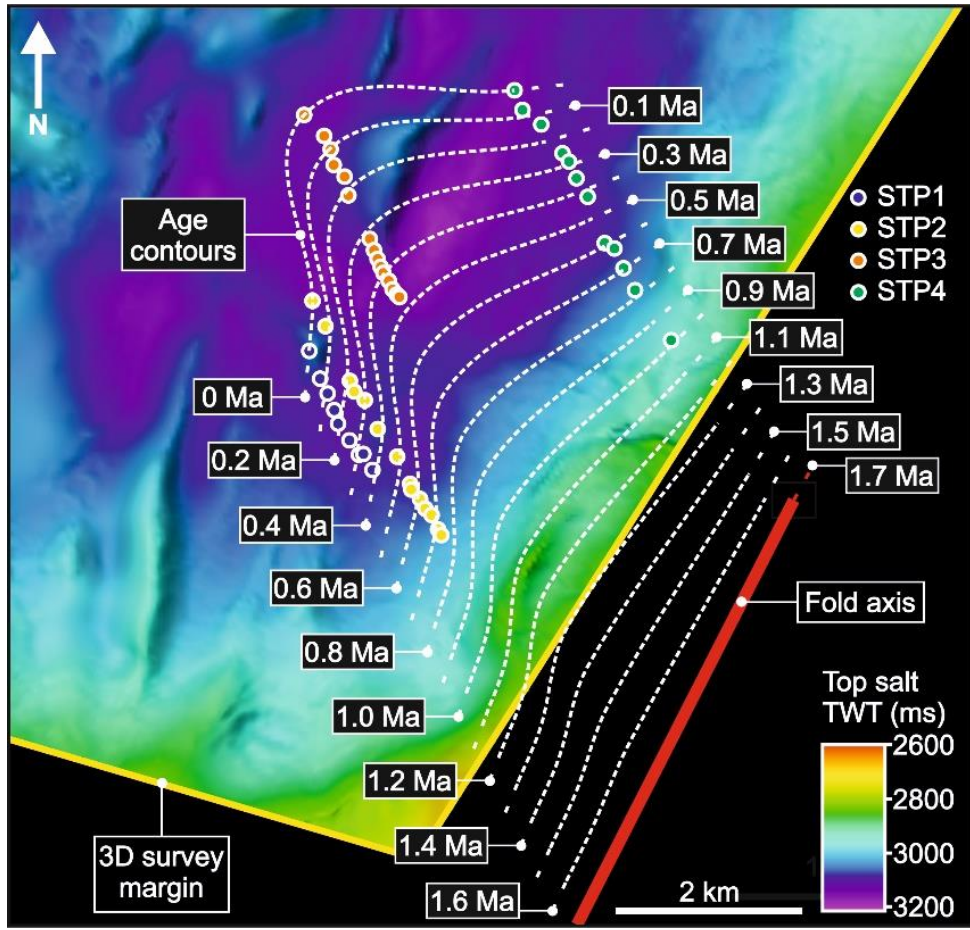

Figure 11. Planform flow of a salt layer. The pockmark distribution shows unidirectional salt flow over few km, however the flow velocity and therefore cumulative strain varies. Contours showing the evolution of the planform flow geometry of the salt over the last $1.7 \mathrm{Ma}( \pm 0.3 \mathrm{Ma})$ are displayed. These are created based on the distance between the fold axis and the first pockmark in each trail and the age of the pockmarks. The outermost contour from the fold axis demonstrates the present day deformed geometry of the salt in planform. 


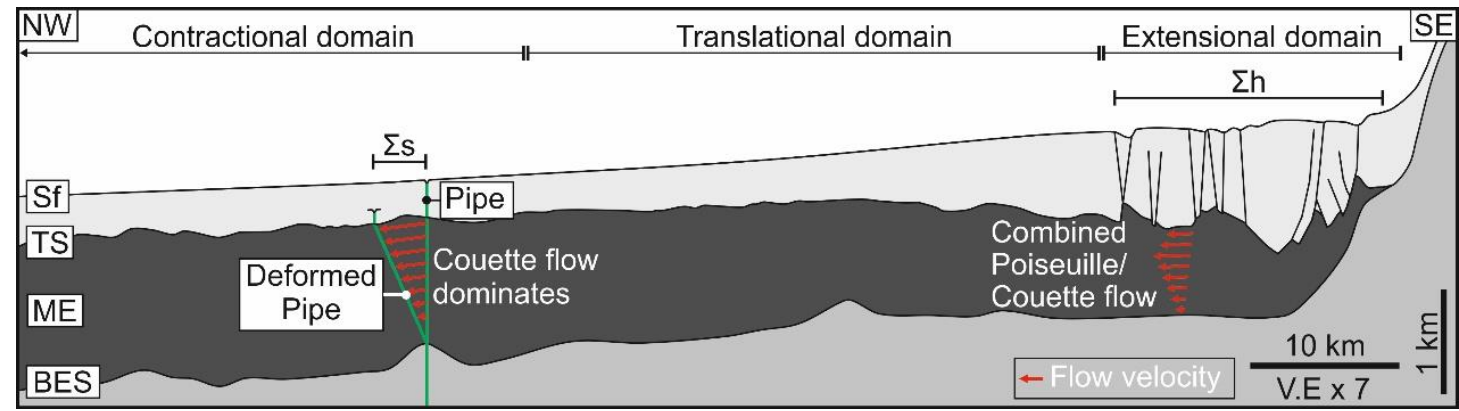

1090 Figure 12. A schematic cross section of the salt kinematics in the Levant Basin. The salt flow regime 1091 transitions from an inferred combined Poisueille/Couette in the extensional domain, to dominantly 1092 Couette as measured in the contractional domain. The cumulative heave in the extensional domain 1093 is approximately balance with cumulative strain $\Sigma$ s measured from the deformed pipe in the 1094 translational-contractional domain. Sf - Seafloor; TS - Top salt; ME - Messinian Evaporites; BES 1095 - Bottom Erosional Surface. 